Yeshiva University, Cardozo School of Law

LARC @ Cardozo Law

2003

\title{
Queers Anonymous: Lesbians, Gay Men, Free Speech, and Cyberspace
}

\author{
Edward Stein \\ Benjamin N. Cardozo School of Law, estein2@yu.edu
}

Follow this and additional works at: https://larc.cardozo.yu.edu/faculty-articles

Part of the Law Commons

\section{Recommended Citation}

Edward Stein, Queers Anonymous: Lesbians, Gay Men, Free Speech, and Cyberspace, 38 Harvard Civil Rights-Civil Liberties Law Review 159 (2003).

Available at: https://larc.cardozo.yu.edu/faculty-articles/400 accepted for inclusion in Articles by an authorized administrator of LARC @ Cardozo Law. For more information, please contact larc@yu.edu. 


\title{
Queers Anonymous: Lesbians, Gay Men, Free Speech, and Cyberspace
}

\section{Edward Stein*}

\begin{abstract}
Anonymity is a shield from the tyranny of the majority. It thus exemplifies the purpose behind the Bill of Rights and of the First Amendment in particular: to protect unpopular individuals from retaliation - and their ideas from suppression - at the hand of an intolerant society. ${ }^{1}$
\end{abstract}

Pseudonymity allows people who are experimenting with different sorts of interests to do so without social repercussions. People can temporarily obscure their real life and play with a different conception of what their life might be. ${ }^{2}$

\section{INTRODUCTION}

The expansion of cyberspace in the past decade has created unprecedented opportunities for communication, both across the globe and across the street. The Internet and other forms of cyberspace have provided new avenues for anonymous and pseudonymous communication. Individuals can now interact without the traditional constraints of time, place, and manner of communication.

As the number of people using cyberspace and the ways they can use it have dramatically increased, governments have attempted to regulate speech in cyberspace through various means. In the United States, the

* Associate Professor of Law, Benjamin N. Cardozo School of Law; Ph.D., Massachusetts Institute of Technology; J.D., Yale Law School; B.A., Williams College. Thanks to James Boyle, William Eskridge, Owen Fiss, Katherine Franke, Janet Halley, Elizabeth Hillman, Morris Kaplan, Jerry Kang, Daphne Keller, Steve Lin, Stephen Munzer, William Rubenstein, Rose Saxe, and Kenji Yoshino for provocative conversations, helpful suggestions, and comments on earlier drafts of this Article. This Article was completed while I was on leave from Cardozo working as a law clerk for the Honorable Judge Dolores Sloviter of the United States Court of Appeals for the Third Circuit. Judge Sloviter and my co-clerks, Forrest Alogna and Dahlia Fetouh, provided a supportive, engaging, enriching, and collegial work environment. Versions of this Article were presented at UCLA Law School, Rutgers-Camden Law School, and the Law, Culture and Humanities Conference held in March 2002 at the University of Pennsylvania Law School.

${ }^{1}$ McIntyre v. Ohio Elections Comm'n, 514 U.S. 334, 357 (1995) (citation omitted).

${ }^{2}$ Ben Greenman, Liar Liar, YAHOo! INTERNET Life, Mar. 1999, at 89, 91 (quoting Professor Jerry Kang, UCLA Law School). 
most notable examples are the Communications Decency Act (CDA), ${ }^{3}$ the Children's Online Protection Act (COPA) ${ }^{4}$ and the Children's Internet Protection Act (CIPA). ${ }^{5}$ Several states have also passed laws or instituted policies that seek to regulate speech in cyberspace, ${ }^{6}$ and further governmental efforts to do so can be expected. ${ }^{7}$

${ }^{3} 47$ U.S.C. § 223(a)-(e) (2000). Subsections (a)(1)(B), (b), and (d)(1)-(2) of the statute were held unconstitutional by ACLU v. Reno, 521 U.S. 844 (1997), aff'g 929 F. Supp. 824 (E.D. Pa. 1996) (“ACLU v. Reno I").

${ }^{4} 47$ U.S.C. $\$ 231$ (2000). A preliminary injunction against enforcement of this section was granted by a district court. ACLU v. Reno, 31 F. Supp. 2d 473 (E.D. Pa. 1999) ("ACLU v. Reno II"). Although the district court's decision was upheld by the Third Circuit, the Supreme Court, though refusing to decide whether the statute might be unconstitutional on other grounds, overruled the Third Circuit's limited grounds for affirming the unconstitutionality of this section and remanded to that court for further proceedings. See Ashcroft v. ACLU, 122 S. Ct. 1700, 1713-14 (2002), vacating ACLU v. Reno, 217 F.3d 162 (3d Cir. 2000). The Court did not, however, vacate the district court's preliminary injunction, and the federal government remains enjoined from enforcing the statute during the pendency of the Third Circuit's further proceedings. Id.

520 U.S.C. \& 9134(f) (2000); 47 U.S.C. § 254(h)(6) (2000). Pursuant to a provision in the Children's Online Protection Act allowing for immediate review of the constitutionality of the Act by a three-judge panel, followed by direct appeal to the United States Supreme Court, a three-judge panel found these sections unconstitutional as a violation of the First Amendment; the Supreme Court's review of that decision is pending. Am. Library Ass'n v. United States, 201 F. Supp. 2d 401 (E.D. Pa. 2002), prob. juris. noted, 2002 WL 31060372 (U.S. Nov. 12, 2002) (No. 02-361).

${ }^{6}$ See, e.g., GA. CODE ANN. § 16-9-93.1(a) (1999) (prohibiting the use of a computer to falsely identify the user) (law preliminarily enjoined on free speech grounds, ACLU v. Miller, 977 F. Supp. 1228 (N.D. Ga. 1997)); Мich. Comp. Laws ANN. § 722.675 (West 1993 \& Supp. 2002) (banning distribution of sexually explicit material to minors over the Internet) (state preliminarily enjoined from enforcement on First Amendment and Commerce Clause grounds, Cyberspace Communications, Inc. v. Engler, 55 F. Supp. 2d 737 (E.D. Mich. 1999), aff'd, 238 F.3d 420 (6th Cir. 2000)); N.M. Stat. AnN. § 30-37-3.2(A) (Michie Supp. 2002) (prohibiting dissemination by computer of material that is harmful to a minor) (preliminary injunction against enforcement of statute on First Amendment and Commerce Clause grounds upheld, ACLU v. Johnson, 194 F.3d 1149 (10th Cir. 1999), aff'g 4 F. Supp. 2d 1029 (D.N.M. 1998)); N.Y. Penal LaW § 235.21(3) (McKinney 2000) (prohibiting intentionally engaging in communication with a minor that "depicts actual or simulated nudity [or] sexual conduct ... and which is harmful to minors") (law preliminarily enjoined on Commerce Clause grounds, Am. Libraries Ass'n v. Pataki, 969 F. Supp. 160 (S.D.N.Y. 1997)); VA. CoDE ANN. \$ 2.2-2827 (Michie 2001) (recodification of VA. Code AnN. \$2.1-804 to -806 (Michie Supp. 2000)) (prohibiting state employees from accessing sexually explicit material on computers owned or leased by the state) (section initially held unconstitutional on First Amendment grounds but then found constitutional by the Fourth Circuit on appellate review, Urofsky v. Allen, 995 F. Supp. 634 (E.D. Va. 1998), rev'd en banc sub nom. Urofsky v. Gilmore, 216 F.3d 401 (4th Cir. 2000), cert. denied, 531 U.S. 1070 (2001)); VA. CoDE ANN. § 18.2-391 (Michie Supp. 2002) (prohibiting intentional display of sexually explicit material to minors for commercial purposes) (permanently enjoined on First Amendment and Commerce Clause grounds, PSINet, Inc. v. Chapman, 167 F. Supp. 2d 878 (W.D. Va. 2001)); see also Mainstream Loudoun v. Bd. of Trs. of the Loudoun County Library, 24 F. Supp. 2d 552 (E.D. Va. 1998) (finding a library's policy requiring the use of filtering software on computers available for public access to be unconstitutional).

${ }^{7}$ See, e.g., Assemb. B. 151, 2001-2002 Reg. Sess. (Cal. 2001) (proposing state law similar to CIPA); S.B. 3414, 224th Ann. Legis. Sess. (N.Y. 2001) (proposing a prohibition on using library computers to access obscene material or child pornography); H.B. 8 , 124th Gen. Assemb., Reg. Sess. (Ohio 2001), enacted as Ohio Rev. Code AnN. 
This Article focuses on a community that is particularly affected by the regulation of speech in cyberspace ${ }^{8}$ namely lesbians, gay men, and other sexual minorities. ${ }^{9}$ It argues that protecting the speech of lesbians, gay men and other sexual minorities is at the heart of the First Amendment and that attempts to regulate such speech should be closely scrutinized. This Article suggests that the regulation of speech in cyberspace uniquely impacts lesbian and gay speech and concludes that such regulation should be subject to close judicial scrutiny.

Given the pervasive effects of regulation on the lesbian and gay community, it is unsurprising that among the litigants challenging almost every attempt to regulate speech in cyberspace in the United States have been lesbians and gay men, the businesses that serve them, or the organizations that represent their interests. Among those challenging the CDA in $A C L U$ v. Reno $I$ were the Queer Resources Directory, an online resource for lesbians, gay men and other sexual minorities, and an AIDS education group that maintains a Web site. ${ }^{10}$ Among those challenging COPA in ACLU v. Reno II were A Different Light Bookstore, a gay and lesbian bookstore that maintains a Web site, Blackstripe, a Web-based resource for African American lesbians and gay men, Philadelphia Gay News, a newspaper serving the lesbian and gay community that also publishes online, and Planet Out, an online content provider serving the les-

$\S 2907.01$ (J) (West, WESTLAW through Oct. 1, 2002, including File 185 of 125 th Gen. Assemb. (2001-2002)) (expanding the definition of material in sex offense laws to include, inter alia, any image appearing on a computer monitor, recorded on a computer disk, or transmitted using the Internet).

${ }^{8}$ Legal scholars have examined the effects of cyberspace on women and racial minorities. See, e.g., Anita L. Allen, Gender and Privacy in Cyberspace, 52 Stan. L. Rev. 1175 (2000); Margaret Chon, Erasing Race?: A Critical Race Feminist View of Internet IdentityShifting, 3 J. Gender, RACE \& Just. 439 (2000); Jerry Kang, Cyber-Race, 113 Harv. L. REv. 1130 (2000). Somewhat related to some of the themes discussed herein is Seth F. Kreimer, Technologies of Protest: Insurgent Social Movements and the First Amendment in the Era of the Internet, 150 U. PA. L. REv. 119, 130 (2001).

${ }^{9}$ In addition to particularly affecting lesbians and gay men, the regulation of speech in cyberspace will also have distinctive impact on bisexuals, transgendered people (people whose sex and sexual identity are discordant), and intersexuals (people who have some male and some female physical/anatomical characteristics). See EdWARD SteIn, The Mismeasure of Desire: The Science, Theory, and Ethics of Sexual Orientation 24-38 (1999) (discussing the differences among sexual minorities). See generally BERNICE L. Hausman, Changing Sex: Transsexualism, Technology, and the Idea of Gender (1995); Suzanne J. Kessler, Lessons from the Intersexed (1998); Kenji Yoshino, The Epistemic Contract of Bisexual Erasure, 52 Stan. L. Rev. 353 (2000). In this Article I focus for the most part on lesbians and gay men but will often use the phrase "lesbians, gay men, and other sexual minorities" to encompass these other groups of people. Typically, even when I use the more restrictive phrase, I mean to include sexual minorities generally. For reasons discussed infra note 123, I do not include people who engage in sex between adults and children. Whether and to what extent other sexual minorities, such as people who engage in sadomasochistic sex, are similarly situated to lesbians and gay men is a question beyond the scope of this Article.

${ }^{10}$ See ACLU v. Reno I, 929 F. Supp. 824, 827 n.2 (E.D. Pa. 1996), aff'd, 521 U.S. 844 (1997). See generally Queer Resources Directory, at http://www.qrd.org (last visited Nov. 9, 2002); Critical Path Project, at http://www.critpath.org (last visited Nov. 9, 2002). 
bian and gay community. ${ }^{11}$ Among those challenging CIPA in American Library Ass'n v. United States are Planet Out, Out in America, a company that runs over sixty Web sites for lesbians, gay men and other sexual minorities, and a young lesbian who accesses the Internet from a public library. ${ }^{12}$ The same pattern emerges among many of the challenges to state laws and policies. ${ }^{13}$

Attempts to regulate cyberspace are of special concern to sexual minorities. Many lesbians and gay men find cyberspace to be an important source of information, a useful way of community and political organizing, a congenial and entertaining way of spending time, and a potential medium for meeting friends, lovers, and sexual partners. ${ }^{14}$ For those who are isolated from other lesbians and gay men in the "real" (that is, physical, non-cyber) world, cyberspace provides a virtual community that constitutes an emotional lifeline. The relative anonymity of cyberspace is ideal for lesbians and gay men who are not open about their sexual orientation and for people who are exploring their sexuality. Cyberspace provides opportunities for which lesbians and gay men as a group, more

${ }^{11}$ See ACLU v. Reno II, 31 F. Supp. 2d 473, 485, 492 (E.D. Pa. 1999) (for this case's complicated procedural history, see supra note 4). See generally A Different Light Bookstore, at http://www.adlbooks.com (last visited Nov. 9, 2002); Blackstripe, at http://www. blackstripe.com (last visited Nov. 9, 2002); Phila. Gay News, at http://www.epgn.com (last visited Nov. 9, 2002); Planet Out, at http://www.planetout.com (last visited Nov. 9, 2002).

${ }_{12}$ See Am. Library Ass'n v. United States, 201 F. Supp. 2d 401, 415-16 (E.D. Pa. 2002), prob. juris. noted, 2002 WL 31060372 (U.S. Nov. 12, 2002) (No. 02-361).

${ }^{13}$ See, e.g., PSINet, Inc. v. Chapman, 108 F. Supp. 2d 611, 613 (W.D. Va. 2000) (listing as among the plaintiffs A Different Light Bookstore and the Lambda Rising Bookstore, both gay and lesbian bookstores that have maintained or do maintain Web sites, and Susie Bright, a columnist who writes about lesbian sex and other gay issues and maintains a Web site at http://www.susiebright.com (last visited Nov. 9, 2002)); Cyberspace Communications, Inc. v. Engler, 55 F. Supp. 2d 737, 746 (E.D. Mich. 1999) (listing as among the plaintiffs GLAD Day Bookshop, a store specializing in lesbian and gay books, with a Web site at http://www.gladdaybookshop.com (last visited Nov. 9, 2002), and the AIDS Partnership of Michigan, which had maintained a Web site), aff'd, 238 F.2d 420 (6th Cir. 2000); ACLU v. Johnson, 4 F. Supp. 2d 1029, 1032 (D.N.M. 1998) (noting that among the activities in which the plaintiffs engage is providing online resources for lesbian and gay youth), aff'd, 194 F.3d 1149 (10th Cir. 1999); Urofsky v. Allen, 995 F. Supp. 634, 635 (E.D. Va. 1998) (listing as among the plaintiffs Professor Heller, who conducted research on lesbian and gay studies using a state university's computer), rev'd en banc sub nom. Urofsky v. Gilmore, 216 F.3d 401 (9th Cir. 2000), cert. denied, 531 U.S. 1070 (2001); Mainstream Loudoun v. Bd. of Trs. of Loudoun County Library, 24 F. Supp. 2d. 552, 557 (E.D. Va. 1998) (listing as among the plaintiffs Books for Gay and Lesbian Teens/Youth, which maintains a Web site at http://www.youth.org/yao/docs/books.html (last visited Nov. 9, 2002), and The Renaissance Transgender Association, the Web address of which is http://www. ren.org (last visited Nov. 9, 2002)); ACLU v. Miller, No. 96-cv-2475-MHS, 1997 U.S. Dist. LEXIS 1446, at *1 (N.D. Ga. June 20, 1997) (listing as among the plaintiffs Atlanta Veterans Alliance, a group for gay veterans); Am. Libraries Ass'n v. Pataki, 969 F. Supp. 160, 162 (S.D.N.Y. 1997) (listing as among the plaintiffs New York City Net, a for-profit Internet service provider catering primarily to lesbians and gay men in the New York area).

${ }^{14}$ See JefF Dawson, Gay and Lesbian Online: Your Indispensable Guide to Cruising The Queer Web (4th ed. 2000); Jennifer Egan, Lonely Gay Teen Seeking Same, N.Y. Times, Dec. 10, 2000, $\$ 6$ (Magazine), at 110; Steve Friess, Cyber Activism, AdvoCATE, Mar. 2, 1999, at 35. 
than heterosexuals as a group, have a particular need. This Article therefore focuses on the intersection of the First Amendment, cyberspace, and the social and legal circumstances of lesbians and gay men.

Laws that restrict the expression of lesbians and gay men in cyberspace disrupt one of the central functions of the First Amendment, namely "to protect ... unpopular individuals from retaliation ... and their ideas from suppression." 15 While all non-dominant groups, including women and racial minorities, are affected by attempts to regulate cyberspace ${ }^{16}$ restrictions on anonymity uniquely affect "closeted" lesbians, gay men, and other sexual minorities. When governments regulate cyberspace, they must consider the impact of potential legislation on lesbians and gay men and safeguard against the suppression of unpopular groups and ideas; when courts evaluate these regulations, they should subject efforts to limit the speech of lesbians and gay men to close judicial scrutiny.

My discussion will proceed as follows. In Part II, I discuss cyberspace and attempts to regulate it. In Part III, I survey the social and legal conditions for lesbians, gay men, and bisexuals in the United States and look at how these conditions are manifest in cyberspace. In Part IV, I explore the ways in which courts have dealt with the speech of sexual minorities. While I show that since the middle of the twentieth century, speech concerning homosexuality and the speech of lesbians and gay men have, for the most part, been protected by the First Amendment, I focus on the exceptions to this protection. In Part V, I discuss anonymous speech. In particular, I examine the Supreme Court's holding that the protection of at least some anonymous speech is an important part of the right to free speech. In Part VI, drawing on the three preceding Parts, I argue that the First Amendment fundamentally protects lesbians and gay men who speak "from the closet," that is, who speak anonymously or pseudonymously. In Part VII, I argue that when lesbians and gay men speak openly rather than from the closet, their speech is political and thus also central to the First Amendment. In Part VIII, I apply the conclusions of the two preceding Parts to cyberspace and suggest that the speech of lesbians and gay men in cyberspace, whether anonymous or not, deserves special protection. I demonstrate how these conclusions build upon judicial responses to governmental attempts to regulate cyberspace. I argue that restrictions on the speech of lesbians and gay men, particularly in cyberspace, undermine the First Amendment and should therefore be subject to heightened judicial scrutiny.

${ }^{15}$ McIntyre v. Ohio Elections Comm'n, 514 U.S. 334, 357 (1995).

${ }^{16}$ See, e.g., supra note 8. 


\section{Cyberspace and Attempts To Regulate It}

\section{A. Cyberspace Defined}

"Cyberspace" is a catchall phrase for computer-mediated communication; it is the "location" of various electronic interactions. Cyberspace includes communication on and through the Internet, the World Wide Web, electronic mail, Usenet discussion groups, chat rooms, the exchange of digitized images, video, and sounds, as well as other modes of communication. In cyberspace, individuals can, inter alia, shop, bank, conduct research, make friends, keep in touch with family, and engage in political activism. The possibilities for communication in cyberspace are expanding rapidly. ${ }^{17}$

Those who have reservations about speaking openly can participate in almost all of the activities in cyberspace anonymously or pseudonymously. ${ }^{18} \mathrm{~A}$ user of cyberspace can adopt a pseudonym and decline to "attach" any information (or at least any true information) about herself-such as her name, hometown, race, or sexual interests-to this pseudonym. It is usually possible for the state or a motivated, cybersavvy individual to locate the person behind the pseudonym. There are, however, various privacy tools that make such tracing difficult. ${ }^{19}$

\section{B. Attempts To Regulate Cyberspace}

Faced with growing numbers of cyberspace services and users, Congress has attempted to limit certain types of communication in cyberspace. In 1996, Congress enacted the Communications Decency Act (CDA). In general, this Act sought to protect minors from indecent and patently offensive communications in cyberspace by prohibiting anyone from sending or displaying indecent or obscene messages to people under the age of eighteen. ${ }^{20}$ In ACLU v. Reno I, the Supreme Court struck down

${ }^{17}$ For a canonical judicial discussion of cyberspace, see ACLU v. Reno I, 929 F. Supp. 824, 830-38 (E.D. Pa. 1996) (containing extensive findings of fact concerning the nature of cyberspace), aff'd, 521 U.S. 844, 849-57 (1997) (containing a summary of same).

${ }^{18}$ Pseudonymity allows an individual to use a name other than her own in cyberspace. This provides limited anonymity because pseudonyms can typically be traced back to the user (with varying degrees of difficulty). Something closer to complete anonymity can be provided through various technological means, including so-called anonymous remailers. See Noah Levine, Note, Establishing Legal Accountability for Anonymous Communication in Cyberspace, 96 Colum. L. Rev. 1526, 1528 n.9 (1996). Henceforth, I use the word "anonymity" to encompass pseudonymity.

${ }^{19}$ See, e.g., Anonymizer.com, at http://www.anonymizer.com (providing access to downloadable software, including a version that is free of charge, that allows users to send e-mail, post messages, and access Web sites anonymously-that is, without allowing for the possibility that the activities can be traced back to the user); see also Shawn C. Helms, Translating Privacy Values with Technology, 7 B.U. J. SCI. \& TeCH. L. 288, 316 (2001), available at http://www.bu.edu/law/scitech/volume7/Helms.pdf.

${ }^{20}$ The statute reads in part: 
the CDA on the grounds that it violated the First Amendment protection of speech. ${ }^{21}$ The Court held that the CDA was overly broad because it unduly restricted adult access in order to protect children ${ }^{22}$ and because it regulated "indecent" speech protected by the First Amendment along with obscene speech, ${ }^{23}$ which is not protected by the First Amendment. ${ }^{24}$ Further, the Court held that the CDA violated the First Amendment because, although the government's interest in protecting children is compelling, there are less restrictive ways of attempting to protect children than those adopted by the CDA. ${ }^{25}$

Congress responded to the Supreme Court's decision in ACLU v. Reno I with the Child Online Protection Act (COPA). This Act prohibited the following conduct:

Whoever knowingly ... in interstate or foreign commerce by means of the World Wide Web, makes any communication for commercial purposes that is available to any minor and that includes material that is harmful to minors shall be fined not more than $\$ 50,000$, imprisoned not more than six months, or both. ${ }^{26}$

COPA defines material harmful to minors as:

(a) Whoever (1) in interstate or foreign communications ... (B) by means of a telecommunications device knowingly (i) makes, creates, or solicits, and (ii) initiates the transmission of, any comment, request, suggestion, proposal, image, or other communication which is obscene or indecent, knowing that the recipient of the communication is under 18 years of age, regardless of whether the maker of such communication placed the call or initiated the communication; ... (2) knowingly permits any telecommunications facility under his control to be used for any activity prohibited by paragraph (1) with the intent that it be used for such activity, shall be fined under Title 18, or imprisoned not more than two years, or both . . . .

(d) Whoever (1) in interstate or foreign communications knowingly (A) uses an interactive computer service to send to a specific person or persons under 18 years of age, or (B) uses any interactive computer service to display in a manner available to a person under 18 years of age, any comment, request, suggestion, proposal, image, or other communication that, in context, depicts or describes, in terms patently offensive as measured by contemporary community standards, sexual or excretory activities or organs, regardless of whether the user of such service placed the call or initiated the communication; or (2) knowingly permits any telecommunications facility under such person's control to be used for an activity prohibited by paragraph (1) with the intent that it be used for such activity, shall be fined under Title 18, or imprisoned not more than two years, or both.

47 U.S.C. $\$ 223(\mathrm{a}),(\mathrm{d})(2000)$.

${ }^{21}$ See ACLU v. Reno I, 521 U.S. 544, 870 (1997).

${ }^{22}$ Id. at 874-75.

${ }^{23}$ See, e.g., Miller v. California, 413 U.S. 15 (1973) (defining obscenity as explicitly sexual speech that primarily appeals to prurient interest in sex, that is offensive to community standards, and that lacks serious literary, scientific, artistic, or political value).

${ }^{24}$ ACLU v. Reno I, 521 U.S. at 871.

${ }^{25}$ Id. at $878-79$.

2647 U.S.C. $\$ 231$ (2000). 
[A]ny communication, picture, image, graphic image file, article, recording, writing, or other matter of any kind that is obscene or that (A) the average person, applying contemporary community standards, would find, taking the material as a whole and with respect to minors, is designed to appeal to, or is designed to pander to, the prurient interest; (B) depicts, describes, or represents, in a manner patently offensive with respect to minors, an actual or simulated sexual act or sexual contact, an actual or simulated normal or perverted sexual act, or a lewd exhibition of the genitals or post-pubescent female breast; and (C) taken as a whole, lacks serious literary, artistic, political, or scientific value for minors. ${ }^{27}$

Various plaintiffs filed suit to prevent the enforcement of COPA, arguing that the statute was unconstitutional. The district court granted a preliminary injunction prohibiting the enforcement of COPA on the grounds that it violated the First Amendment, ${ }^{28}$ finding that COPA imposed a significant burden on the speech of people who make use of cyberspace and that it failed to use the least restrictive means for doing so. The Court of Appeals for the Third Circuit affirmed on the grounds that the statute was overbroad insofar as it gauged harm to minors by contemporary community standards. ${ }^{29}$

In a highly fractured opinion, the Supreme Court vacated that decision and remanded the case to the Court of Appeals. Justice Thomas' opinion, only part of which commanded a five-judge majority, focused on the "narrow question [of] whether [COPA's] use of 'community standards' to identify 'material that is harmful to minors' violates the First

${ }^{27} I d . \S 231(\mathrm{e})(6)$.

${ }^{28}$ ACLU v. Reno II, 31 F. Supp. 2 d 473 (E.D. Pa. 1999).

${ }^{29}$ ACLU v. Reno II, 217 F.3d 162, 173-74 (3d Cir. 2000), vacated and remanded sub nom. Ashcroft v. ACLU, 122 S.Ct. 1700 (2002). The Third Circuit explicitly did not reach other issues addressed by the district court below:

[W]e do not find it necessary to address the District Court's analysis of the definition of "commercial purposes"; whether the breadth of the forms of content covered by COPA could have been more narrowly tailored; whether the affirmative defenses impose too great a burden on web publishers or whether those affirmative defenses should have been included as elements of the crime itself; whether COPA's inclusion of criminal as well as civil penalties was excessive; whether COPA is designed to include communications made in chat rooms, discussion groups and links to other websites; whether the government is entitled to so restrict communications when children will continue to be able to access foreign websites and other sources of material that is harmful to them; what taken "as a whole" should mean in the context of the web and the Internet; or whether the statute's failure to distinguish between material that is harmful to a six year old versus a sixteen year old is problematic.

Id. at $174 \mathrm{n} .19$. On remand, the Third Circuit will undoubtedly address these issues. 
Amendment." 30 The Court found that COPA's use of community standards did not render it facially unconstitutional and remanded the case for further constitutional analysis of COPA. While eight of the justices concurred in the result, only two judges joined Justice Thomas in the most substantive sections of his opinion. ${ }^{31}$

Because of the fractured nature of the Court's decision and the narrowness of its holding, it is difficult to discern what the Court will do if, as seems likely, the Third Circuit, on remand, holds that COPA is unconstitutional on other grounds. Justice Kennedy's concurring opinion suggests that he and Justices Souter and Ginsburg have serious doubts about COPA's constitutionality. ${ }^{32}$ Justice Stevens, who dissented, would have affirmed the decision of the Court of Appeals. Justices Breyer and O'Connor are likely to be the swing votes when, as seems inevitable, COPA again reaches the Supreme Court. Their separate concurrences, both of which focus on the constitutionality of a national standard for obscenity, do not provide much indication of their views on COPA as a whole. ${ }^{33}$

Various states have passed laws like the CDA or COPA. For example, in 1999, Michigan passed a law that banned the distribution of sexually explicit material to minors over the Internet. ${ }^{34}$ In Cyberspace Communications, Inc. v. Engler, this law was preliminarily enjoined against enforcement on the basis that it likely violated the First Amendment and the Commerce Clause. ${ }^{35}$ Other such state laws have been enjoined on similar grounds. ${ }^{36}$

\section{Filtering}

Various courts, in addressing the constitutionality of the CDA, COPA, and similar state laws have found that the use of filtering software that blocks access to certain Web sites is a less restrictive means of fulfilling the legitimate government interest in preventing children from accessing

${ }^{30}$ Ashcroft v. ACLU, 122 S. Ct. 1700, 1703 (2002). Chief Justice Rehnquist and Justice Scalia joined the entirety of Justice Thomas's opinion. Justice O'Connor joined parts I, II, and IV, as well as part III-B. Justice Breyer joined parts I, II, and IV.

${ }^{31}$ See id. at 1708-13 (Part III, sections A, B, and D, of Justice Thomas's opinion were joined only by Justices Rehnquist and Scalia); id. at 1714 (O'Connor, J., concurring in part and concurring in the judgment); $i d$. at 1715 (Breyer, J., concurring in part and concurring in the judgment); id. at 1716 (Kennedy, J., joined by Souter, J., and Ginsburg, J., concurring in the judgment).

${ }^{32}$ Id. at 1716 (Kennedy, J., concurring in the judgment) ("There is a very real likelihood that [COPA] is overbroad and cannot survive [a facial] challenge."); id. at 1722 (Kennedy, J., concurring in the judgment) ("The Court of Appeals['] ... ultimate conclusion may prove correct. There may be grave doubts that COPA is consistent with the First Amendment.").

${ }^{33}$ See id. at 1715 (O'Connor, J., concurring in part and concurring in the judgment); $i d$. at 1716 (Breyer, J., concurring in part and concurring in the judgment).

${ }^{34}$ Мich. Comp. Laws ANN. § 722.675 (West 1993 \& Supp. 2002).

${ }^{35} 55$ F. Supp. 2d 737 (E.D. Mich. 1999), aff'd, 238 F.3d 420 (6th Cir. 2000).

${ }^{36}$ See supra note 6. 
obscene and indecent material in cyberspace. ${ }^{37}$ Such software allows individual parents to control their children's access to cyberspace. The virtue of such software is that when parents are in control, the state need neither restrict speech in cyberspace nor restrict access to cyberspace.

There are various types of filtering methods, of which the two most frequently used are keyword blocking filters and site-blocking filters. The less sophisticated type of filters search for certain undesirable ("dirty") keywords or phrases and then remove these words or phrases from the page or, alternatively, block pages containing such words. Such keyword filters are unsophisticated because they unintentionally block out many sites. For example, a filter that attempts to prevent access to sexually explicit Web sites by screening out the word "sex" would also screen out Web pages with information about sextuplets and musical sextets, as well as sexual orientation and perhaps even the Mars Explorer (in which the letters "s," "e," and " $x$ " are adjacent). ${ }^{38}$

More sophisticated are programs that use site-blocking filters (or programs that combine such filters with "dirty word" blocking filters). These types of filtering programs maintain lists of Web sites and either (a) prohibit access to all the sites on the list ("black-list" filters) or (b) permit access to only those sites on the list ("white-list" filters). While each method faces serious limitations, ${ }^{39}$ white-list filters (like that used by AOL in its "Young Teen" area $^{40}$ ) provide greater assurance that the filtered sites will be free of offending material, because each site has been screened and then specifically included on the list of accessible sites. However, these filtering methods are limited in that they only provide access to specified sites. New Web pages that have not yet been scrutinized will also be blocked.

${ }^{37}$ See, e.g., ACLU v. Reno I, 521 U.S. 844, 877 (1997).

${ }^{38}$ An early version of the filtering program CYBERsitter did not actually block access to a Web page because the page contained a prohibited word; rather, it displayed the page, but ommitted the word. Because this version of the program included "homosexual" among its "dirty words," a Web page that contained the sentence "The Catholic Church opposes homosexual marriage" would be rendered by CYBERsitter as "The Catholic Church opposes marriage." Peacefire, CYBERsitter Examined, at http://peacefire.org/censorware/CYBERsitter (last visited Nov. 9, 2002); see also Gay \& Lesbian Alliance Against Defamation, Access Denied Version 2.0: The Continuing Threat Against Internet Access and Privacy and Its Impact on the Lesbian, Gay, Bisexual and Transgender Community 17 (Dec. 1999), available at http://www.glaad.org/org/binary-data/GLAAD_PDF/pdf_file/2.pdf [hereinafter ACCESS DENIED].

${ }^{39}$ For a detailed general discussion of the limitations of filtering software, see American Library Ass'n v. United States, 201 F. Supp. 2d 401, 428-50 (E.D. Pa. 2002), prob. juris. noted, 2002 WL 31060372 (U.S. Nov. 12, 2002) (No. 02-361).

${ }^{40}$ Digital Chaperones for Kids, Consumer ReP., Mar. 2001, at 20 [hereinafter Digital Chaperones]. A similar filtering method was used in 1996 by a library in Westerville, Ohio. Computers in the children's section of the library were restricted to a few thousand sites chosen by librarians. After three years, the library stopped using this system because it dramatically constrained the material children could access in cyberspace. See Am. Library Ass'n, 201 F. Supp. 2d at 424-25. 
Both white-list and black-list filters must be constructed and maintained through human intervention. Because of the size of the Web and the difficulties involved in rating each Web site and keeping the ratings up-to-date, neither type of filter will be effective. White-list filters require frequent maintenance to ensure that sites that were originally approved do not add offending content; otherwise, they will fail to provide the pristine content they purport to deliver. A huge staff would be necessary to evaluate even a significant portion of existing Web sites to determine which ones should be filtered. Even if such a staff could be assembled, the people who do the screening would have to make subjective determinations about each site they screen. To do their job properly, the screeners would have to assess whether each site's content is appropriate for different age groups and in light of varied filtering criteria. A siteblocking program that uses a black-list filter will probably not screen out most offensive content. For example, in an independent study, the filtering program Cybersnoop failed to block ninety percent of objectionable sites. ${ }^{41}$ Additionally, most site-blocking software blocks access to some lesbian and gay material, much of which is clearly not offensive. ${ }^{42}$

Many states and the Federal government have turned to filtering software, despite its limitations, in light of the negative judicial assessment of CDA, COPA and similar statutes. For example, the public libraries in Loudoun County, Virginia, as part of providing Internet access to its patrons, installed such a program (a filtering program called XSTOP) on its public terminals. The library's policy for Internet access provided, in part, that:

all library computers would be equipped with site-blocking software to block all sites displaying ... child pornography and obscene material; and ... material deemed harmful to juveniles; ... all library computers would be installed near or in full view of library staff; [and that] ... patrons would not be permitted to access pornography $\ldots{ }^{43}$

A nonprofit organization, several county residents, and two Web pages directed at sexual minorities filed suit in federal court challenging the library's Internet policy, arguing that it violated their free speech rights.

${ }^{41}$ Digital Chaperones, supra note 40.

${ }^{42}$ See, e.g., Am. Library Ass'n, 201 F. Supp. 2d at 445-47 (listing several Web sites with gay and lesbian content in its discussion of erroneously blocked Web sites); AccESS Denied, supra note 38; Lisa Guernsey, Sticks and Stones Can Hurt, but Bad Words Pay, N.Y. Times, Apr. 8, 1999, at G1 (discussing filtering software and mentioning one widely used program that prohibits access to any site that uses the phrase "gay rights"); see also Digital Chaperones, supra note 40 (noting that some filters are likely to curb access to Web sites that discuss political and social issues).

${ }^{43}$ Mainstream Loudoun v. Bd. of Trs. of the Loudoun County Library, 24 F. Supp. 2d, 552, 556 (E.D. Va. 1998). 
The district court ruled in favor of the plaintiffs, holding that the library's Internet access policy violated the First Amendment because, in part, it restricted the access of adult patrons in order to protect minors and because it was neither necessary for nor narrowly tailored to any compelling state interest. ${ }^{44}$

The decision in Mainstream Loudoun did not discourage Congress from passing a law requiring use of filtering software. In 2000, Congress passed the Children's Internet Protection Act ("CIPA"), ${ }^{45}$ which requires public schools and libraries to install filtering software that prohibits access to obscene material, child pornography, or material that is harmful to minors, in order to be eligible for certain federal funding. ${ }^{46}$ Library or school personnel may disable the filtering software for certain adult users who can demonstrate that they are engaged in a "bona fide research program" 47 that requires unfiltered access to cyberspace, but neither provision defines a bona fide research program or says how library or school personnel can make the necessary assessments of the proposed research and do so in a way that protects users' privacy.

A three-judge panel recently found CIPA unconstitutional, applying strict scrutiny to content-based restrictions on library patrons' access to cyberspace. ${ }^{48}$ The court held that the mandatory use of filtering software is not narrowly tailored to a compelling governmental interest. ${ }^{49}$ Specifically, the court found that the filtering software, because of its technological limitations, "block[s] access to substantial amounts of constitutionally protected speech." ${ }^{50}$ Further, the court found that while libraries do allow access to blocked sites when a library patron requests, this method of dealing with the technological limitations of filtering programs "will deter many patrons because they are embarrassed, or desire to protect their privacy or remain anonymous." ${ }^{51}$ The fact that libraries will disable filtering on request does not, according to the court, "cure the constitutional deficiencies in public libraries' use of Internet filters." 52

44 Id at 570.

${ }^{45}$ Pub. L. No. 106-554, 114 Stat. 2763 (2000) (codified in various scattered sections of the U.S. Code.)

${ }^{46}$ Specifically, one portion of CIPA requires public libraries that receive federal funds through a program designed to provide access to information services such as the Internet to install filtering technology to prohibit access to obscene material, child pornography and, if the computers involved are used by minors, material that is harmful to minors. 47 U.S.C. $\S 254$ (2000). Another portion requires libraries that receive funding for computer equipment or Internet access from the Library Services and Technology Act to take similar measures. 20 U.S.C. $\S 9134$ (2000).

${ }^{47} 20$ U.S.C. \& 9134(f)(3); 47 U.S.C. \& 254(h)(5)(D) (2000).

${ }^{48}$ Am. Library Ass'n v. United States, 201 F. Supp. 2d 401, 453-70 (E.D. Pa. 2002) (discussing the level of scrutiny applicable to library use of filtering software), prob. juris. noted, 2002 WL 31060372 (U.S. Nov. 12, 2002) (No. 02-361).

${ }^{49} \mathrm{Id}$. at $470-84$ (applying strict scrutiny).

${ }^{50} I d$. at 410 .

${ }^{51} I d$. at 411 .

${ }^{52} I d$. 
The court concluded that CIPA was facially invalid on First Amendment grounds and enjoined its enforcement.

\section{The Social Situation of Lesbians and Gay Men AND ITS LEGAL ENFORCEMENT}

As background for the discussion of the impact on sexual minorities of attempts to regulate cyberspace, I consider some features of the social situation of lesbians, gay men and other sexual minorities in the United States and their legal enforcement. In the United States, lesbians and gay men face a hostile social environment. Although it seems beyond dispute, Justice Scalia has sought to deny this reality, claiming that homosexuals have both "high disposable income" and "political power much greater than their numbers [that] ... they devote to achieving not merely a grudging social toleration, but full social acceptance, of homosexuality." ${ }^{3}$ The following discussion endeavors to dispel skepticism like Justice Scalia's regarding the severity of anti-gay sentiment and structures in the United States.

\section{A. The Legal Situation of Lesbians and Gay Men}

One way to assess the situation of lesbians and gay men is to examine the laws that are directed at them in particular. In the United States, depending on how one counts, thirteen states as well as the military (which is a separate criminal jurisdiction) have laws that criminalize most forms of same-sex sexual activity ${ }^{54}$ Although no state regularly enforces these laws (called "sodomy" laws or laws regarding "unnatural" sex acts) when adults privately and willingly engage in such activity, in some states, these laws have been selectively applied to gay men and lesbians. ${ }^{55}$ The Supreme Court has ruled, in Bowers v. Hardwick, ${ }^{56}$ that the Constitution allows states to prohibit consensual homosexual activity. Laws against sexual activity between people of the same sex are often used to support and justify other laws and social practices relating to homosexuality. ${ }^{57}$ Criminal prohibitions relating to sexual activity between

${ }^{53}$ Romer v. Evans, 517 U.S. 620, 645-46 (1996) (Scalia, J., dissenting).

${ }^{54}$ Of these states, three (Kansas, Texas, and Oklahoma) have laws that criminalize certain sexual acts only when committed by two people of the same sex. See Kan. STAT. AnN. § 21-3505 (1995); Okla. Stat. tit. 21, § 886 (2001); Tex. Penal Code Ann. \$ 21.06 (Vernon 1994); see also Lambda Legal Defense \& Educ. Fund, State-by-State Map of Sodomy Laws, at http://www.lambdalegal.org/cgi-bin/pages/states/sodomy-map (last visited Nov. 9, 2002).

${ }^{55}$ See, e.g., Diana Hassel, The Use of Criminal Sodomy Laws in Civil Litigation, 79 Tex. L. Rev. 813, 822 n.56 (2001); Christopher Leslie, Creating Criminals: The Injuries Inflicted by Unenforced Sodomy Laws, 35 HaRv. C.R.-C.L. L. REv. 103, 108 n.31 (2000).

56478 U.S. 186, 186 (1986).

${ }^{57}$ For example, in Padula v. Webster, to defend a ban on lesbians and gay men working for the Federal Bureau of Investigation against an equal protection challenge, the D.C. 
people of the same sex restrict sexual behaviors and enforce negative attitudes toward lesbians and gay men. ${ }^{58}$

Not only is sex between people of the same sex criminalized, lesbians, gay men and bisexuals are also subject to a multitude of discriminatory practices. For example, it is legal in thirty-nine states for a non-state entity to discriminate in hiring and housing on the basis of sexual orientation. ${ }^{59}$ In many states, lesbians and gay men face difficulties (often insurmountable) adopting children and, in Florida, they are simply prohibited as a matter of law from adopting ${ }^{60}$ Additionally, no state provides lesbian and gay relationships with the same legal recognition it provides heterosexual marriages; even Vermont, which has been the most progressive state in recognizing same-sex relationships, created an independent category of "civil unions" rather than providing same-sex couples access to the institution of marriage. ${ }^{61}$ Moreover, same-sex couples who obtain civil unions in Vermont do not receive the federal benefits that accrue to married couples, ${ }^{62}$ and their relationship may not be recognized in other

Circuit Court cited the Supreme Court's decision in Bowers. Padula v. Webster, 822 F.2d 97 (D.C. Cir. 1987). The circuit court said, "It would be quite anomalous, on its face, to declare status defined by conduct that states may constitutionally criminalize as deserving of strict scrutiny under the equal protection clause." Id. at 103.

${ }^{58}$ See, e.g., Hassel, supra note 55; Leslie, supra note 55.

${ }^{59}$ See, e.g., Edward Stein, Evaluating the Sex Discrimination Argument for Lesbian and Gay Rights, 49 UCLA L. Rev. 471, 475 n.13 (2001). Title VII does not prevent private employers from discriminating on the basis of sexual orientation. See, e.g., Smith v. Liberty Mut. Ins. Co., 569 F.2d 325 (5th Cir. 1978) (holding that Title VII does not prohibit discrimination on the basis of effeminacy); Dillon v. Frank, No. 90-2290, 1992 WL 5436 (6th Cir. Jan. 15, 1992); Ruth v. Children's Med. Ctr., No. 90-4069, 1991 WL 151158 (6th Cir. Aug. 8, 1991); Williamson v. A.G. Edwards \& Sons, Inc., 876 F.2d 69 (8th Cir. 1989) (per curiam). Various scholars have argued against this interpretation of Title VII. See, e.g., Samuel Marcosson, Harassment on the Basis of Sexual Orientation: A Claim of Sex Discrimination Under Title VII, 81 Geo. L.J. 1 (1992); Bennett Capers, Sex(ual Orientation) and Title VII, 91 Colum. L. Rev. 1158 (1991). For now, legislative change seems the most promising strategy for protecting against employment discrimination on the basis of sexual orientation. See Employment Non-Discrimination Act of 2001, H.R. 2692, 107th Cong. (2001) (proposing to amend Title VII to prohibit sexual orientation discrimination in most employment contexts).

${ }^{60}$ Fla. STAT. ch. 63.042(3) (2001). This law was recently upheld against a constitutional challenge in Lofton v. Kearney, 157 F. Supp. 2d 1372 (S.D. Fla. 2001).

${ }^{6}{ }^{6}$ See, e.g., William N. Eskridge, JR., Equality Practice: Civil Unions and the Future of Gay Rights (2002); William N. Eskridge, Jr., The Case for Same-Sex MARriage (1996) [hereinafter Eskridge, SAME-SeX MARriage].

${ }^{62} 1$ U.S.C. $§ 7$ (2000) ("[T] he word 'marriage' means only a legal union between one man and one woman as husband and wife, and the word 'spouse' refers only to a person of the opposite sex who is a husband or wife."). 
states. ${ }^{63}$ Outside Vermont, same-sex couples are denied access to the vast majority of the rights and privileges that marriage offers. ${ }^{64}$

The legal asymmetries surrounding sexual orientation are not limited to the rights and privileges withheld from gay and lesbian individuals. Rather, they extend to lesbian and gay institutions and community structures. For example, various public schools have denied funding to lesbian and gay student organizations. ${ }^{65}$ In addition, plays, photographs, and other forms of artistic expression that reflect lesbian and gay culture have been prohibited from receiving government support. ${ }^{66}$ In fact, representations of and by lesbians and gay men have played a central role in debates over government funding of the arts and public standards of "decency." ${ }^{67}$

Finally, despite the discrimination faced by lesbians and gay men, past and present, current Supreme Court case law does not afford sexual orientation heightened scrutiny under the Fourteenth Amendment's Equal Protection Clause, as it does for classifications based on race, ethnicity, national origin, sex, alienage, and legitimacy. ${ }^{68}$ While the Supreme Court has not directly ruled on the question of whether sexual-orientation

${ }^{63}$ See 28 U.S.C. $§ 1738$ C (2000) (providing that a state does not have to give full faith and credit to a same-sex marriage legally performed in another state); Burns v. Burns, 560 S.E.2d 47 (Ga. Ct. App. 2002) (holding that a Georgia woman who obtained a civil union in Vermont with her same-sex partner was nevertheless bound by a court decree denying visitation with her children from a previous marriage while "cohabiting" with an adult to whom she is neither married nor related).

${ }^{64}$ See, e.g., Eskridge, SAME-Sex MARRIAGE, supra note 61, at 66-67.

${ }^{65}$ See, e.g., E. High Gay/Straight Alliance v. Bd. of Educ. of Salt Lake City Sch. Dist., 81 F. Supp. 2d 1166 (D. Utah 1999) (finding no violation of 20 U.S.C. § 4071 (2000), a provision of the Equal Access Act, when, in response to the formation of a gay high school student group, the school board barred all "non-curriculum-related" student groups); see also Colin v. Orange Unified Sch. Dist., 83 F. Supp. 2d 1135 (C.D. Cal. 2000) (granting preliminary injunction after finding that the school board's denial of a gay group's request for recognition was likely a violation of the Equal Access Act); E. High Sch. Prism Club v. Seidel, 95 F. Supp. 2d 1239 (D. Utah 2000) (granting preliminary injunction on the basis that a gay student group was likely curriculum-related and had thus probably been improperly prevented from organizing and meeting on school property).

${ }^{66}$ See, e.g., Nat'l Endowment for the Arts v. Finley, 524 U.S. 569 (1998) (upholding a "decency" clause in the NEA's governing statute against a First Amendment challenge by artists, including some lesbian and gay artists).

${ }^{67}$ See, e.g., Nancy Knauer, Homosexuality as Contagion: From the Well of Loneliness to the Boy Scouts, 29 Hofstra L. REv. 401, 495-96 ("Congress and executive agencies have imposed conditions on state-funded speech mandating that it cannot be offensive or outside the bounds of 'general standards of decency.' Often, the decision to include such a subjective standard was intentionally designed to disqualify expressions of same-sex desire.").

${ }^{68}$ See, e.g., Yick Wo v. Hopkins, 118 U.S. 356 (1886) (heightened scrutiny for ethnic classification); Hernandez v. Texas, 347 U.S. 475 (1954) (heightened scrutiny for national origin); Plyler v. Doe, 457 U.S. 202, 218-23 (1982) (heightened scrutiny for alienage); Levy v. Louisiana, 391 U.S. 68 (1968) (heightened scrutiny for legitimacy); Miss. Univ. for Women v. Hogan, 458 U.S. 718, 723-24 (1982) (heightened scrutiny for gender). 
classifications deserve heightened scrutiny, most lower courts that have considered the question have held that they do not. ${ }^{69}$

However, the Supreme Court's decision in Romer v. Evans is instructive. ${ }^{70}$ In Romer, the Court struck down an amendment to the Colorado Constitution. The amendment, which was approved by a state-wide voter referendum, repealed various city ordinances in Colorado that prohibited discrimination on the basis of sexual orientation and, further, prohibited any state or local government from passing laws that would protect lesbians, gay men, and bisexuals from such discrimination. ${ }^{71}$ The Court explicitly did not reach the question of whether sexual orientations deserve heightened scrutiny under the Equal Protection Clause of the Fourteenth Amendment. Rather, it held that the Colorado constitutional amendment failed to pass constitutional muster even under rational review, a weaker standard of judicial scrutiny. Justice Kennedy wrote for the majority:

First, the amendment has the peculiar property of imposing a broad and undifferentiated disability on a single named group, an exceptional and, as we shall explain, invalid form of legislation. Second, its sheer breadth is so discontinuous with the rea-

${ }^{69}$ Several cases have explicitly refused to grant heightened scrutiny for sexual orientation classifications. See, e.g., Ben-Shalom v. Marsh, 881 F.2d 454, 464 (7th Cir. 1989) (refusing to grant heightened scrutiny for sexual orientation classifications in the context of the military's policy on homosexuality); Woodward v. United States, 871 F.2d 1068, 1076 (Fed. Cir. 1989) (same); Padula v. Webster, 822 F.2d 97, 103 (D.C. Cir. 1987) (same in the context of the FBI); Thomasson v. Perry, 80 F.3d 915 (4th Cir. 1996) (en banc) (same in the context of the military's "Don't Ask, Don't Tell" policy). There have been rare exceptions to these decisions, though all have been vacated or reversed on appeal. See, e.g., Watkins v. United States Army, 847 F.2d 1329 (9th Cir. 1988) (holding that sexual orientation classifications deserve heightened scrutiny and, under this standard of review, that the U.S. military's pre-1992 policy of discharging homosexuals was unconstitutional), withdrawn, 875 F.2d 699 (9th Cir. 1989) (en banc); High Tech Gays v. Def. Indus. Sec. Clearance Office, 668 F. Supp. 1361 (N.D. Cal. 1987) (holding that classifications based on homosexuality or perceived homosexuality deserve heightened scrutiny under equal protection), rev'd, 895 F.2d 563 (9th Cir. 1990); Jantz v. Muci, 759 F. Supp. 1543, 1546 (D. Kan. 1991) (same), rev'd, 976 F.2d 623 (10th Cir. 1992); see also Rowland v. Mad River Local Sch. Dist., 470 U.S. 1009 (1985) (Brennan, J., dissenting) (dissenting from denial of writ of certiorari on grounds that discrimination against homosexuals raises significant equal protection concerns).

${ }^{70}$ Romer v. Evans, 517 U.S. 620 (1996).

${ }^{71}$ The amendment at issue in Romer reads, in part:

Neither the State of Colorado, through any of its branches or departments, nor any of its agencies, political subdivisions, municipalities or school districts, shall enact, adopt or enforce any statute, regulation, ordinance or policy whereby homosexual, lesbian or bisexual orientation, conduct, practices or relationships shall constitute or otherwise be the basis of or entitle any person or class of persons to have or claim any minority status, quota preferences, protected status or claim of discrimination.

Colo. Const. art. II, $\S 30 \mathrm{~b}$. 
sons offered for it that the amendment seems inexplicable by anything but animus toward the class that it affects; it lacks a rational relationship to legitimate state interests. ${ }^{72}$

Some scholars have read Romer as suggesting that the Court is in fact applying a somewhat heightened standard of review to sexualorientation classifications, one either equivalent to the intermediate standard of review it applies to gender classifications, ${ }^{73}$ which is a somewhat less searching review than strict scrutiny,${ }^{74}$ or a standard in between mere rational review and conventional intermediate scrutiny-what some have called "rational review with bite."75 Given the highly deferential nature of rational basis review, it seems clear that the Court in Romer had a more rigorous test in mind. Perhaps Romer indicates that heightened scrutiny for sexual orientation is just around the corner. In the meantime, however, various federal courts have applied rational basis review in scrutinizing statutory classifications based on sexual orientation. While some of them have invalidated sexual-orientation discrimination, ${ }^{76}$ others have found that discrimination on the basis of sexual orientation is constitutionally legitimate. ${ }^{77}$

\section{B. Social Attitudes Toward Lesbians and Gay Men}

Legal matters aside, social attitudes toward lesbians and gay men and other sexual minorities, while improving in significant ways, remain predominantly negative. Violence against lesbians and gay men is not

${ }^{72}$ Romer, 517 U.S. at 632

${ }^{73}$ See, e.g., Craig v. Boren, 429 U.S. 190 (1976) (striking down a state law permitting girls to buy low-alcohol beer at a younger age than boys because it made use of sex-based classifications).

${ }^{74}$ But see United States v. Virginia, 518 U.S. 515, 531 (1996) (noting that the justification of a law that makes use of sex-based classifications must be "exceedingly persuasive").

${ }^{75}$ See, e.g., Gayle Lynn Pettinga, Rational Basis With Bite: Intermediate Scrutiny by Any Other Name, 62 IND. L.J. 779 (1987).

${ }^{76}$ Several federal courts have issued decisions that used the rational review standard to overturn laws that make use of sexual orientation classifications. See, e.g., Stemler v. City of Florence, 126 F.3d 856, 873-74 (6th Cir. 1997) (holding that selective prosecution based on sexual orientation fails rational review); Nabozny v. Podlesny, 92 F.3d 446, 458 (7th Cir. 1996) (holding, in part, that there was no "rational basis for permitting one student to assault another based on the victim's sexual orientation"); Glover v. Williamsburg Local Sch. Dist. Bd. of Educ., 20 F. Supp. 2d 1160 (S.D. Ohio 1998) (holding that the decision not to rehire a teacher based solely on sexual orientation fails rational review); Weaver v. Nebo Sch. Dist., 29 F. Supp. 2d 1279 (D. Utah 1998) (holding that the decision not to reassign a public school teacher to coach a volleyball team based on her sexual orientation fails rational review).

${ }^{77}$ See, e.g., Equal. Found. of Greater Cincinnati, Inc. v. Cincinnati, 128 F.3d 289 (6th Cir. 1997); Ben-Shalom v. Marsh, 881 F.2d 454, 464 (7th Cir. 1989); Beller v. Middendorf, 632 F.2d 788 (9th Cir. 1980). 
uncommon.$^{78}$ Such violence is often quite severe, as several hate-crime murders of gay men and lesbians in the past few years have graphically demonstrated..$^{79}$ The prevailing intolerance toward sexual minorities manifests itself in low self-esteem in many lesbians and gay men, especially young ones. As striking evidence of this trend, lesbian and gay teenagers are two to three times more likely to attempt suicide than their heterosexual counterparts. ${ }^{80}$

While national opinion polls indicate that attitudes toward lesbians and gay men are becoming more favorable over time, over forty percent of the population still believes that homosexuality is not an acceptable lifestyle and that same-sex sexual relations between consenting adults should be illegal. ${ }^{81}$ Further, over half of the population opposes laws that would give same-sex couples some of the legal rights of married couples. ${ }^{82} \mathrm{~A}$ recent poll found that approximately fifty-six percent of adult Americans disapprove of homosexual couples adopting children. ${ }^{83}$ Various polls have suggested that substantially more than half of adult Americans would be "upset" or "very upset" if their college-age child said he or she was gay or lesbian. ${ }^{84}$ Read together, these polls demon-

\footnotetext{
${ }^{78}$ See, e.g., Gary David Comstock, Violence Against Lesbians and Gay Men (1991).
}

${ }^{79}$ See Troy A. Scotting, Hate Crimes and the Need for Stronger Federal Legislation, 34 Akron L. Rev. 853, 887-89 (2001); Henry F. Fradella et al., Sexual Orientation, Justice, and Higher Education: Student Attitudes Towards Gay Civil Rights and Hate Crimes, $11 \mathrm{~L}$. \& SeXuality 11, 14 (2002).

${ }^{80}$ Paul Gibson, Gay and Lesbian Youth Suicide, in Sexual Orientation and THE LAW 289 (William Rubenstein ed., 1997); see also Stephen Russell \& Kara Joyner, Adolescent Sexual Orientation and Suicide Risk: Evidence from a National Study, 91 Aм. J. Pub. Health 1276 (2001).

${ }^{81}$ Frank Newport, In Depth Analyses: Homosexuality, Gallup Poll News, Sept., 2002, (finding that, in May 2002, 51\% of surveyed individuals said that "homosexuality should be considered an accepted alternative lifestyle," compared to $34 \%$ in 1982 , and that $52 \%$ said that "homosexual relations between consenting adults should . . . be legal," compared to $43 \%$ in 1977), available at http://gallup.com/poll/analysis/ia020911.asp. A 1998 Gallup poll found that $59 \%$ of American adults believe "homosexual behavior is morally wrong." George Gallup, Jr., The Gallup Poll: Public Opinion 1998, at 89 (1999). This question does not seem to have been asked more recently.

${ }^{82}$ See Newport, supra note 81 (finding that $46 \%$ of those surveyed in 2001 and $51 \%$ of those surveyed in 2002 would "oppose a law that would allow homosexual couples to legally form civil unions, giving them some of the legal rights of married couples").

${ }^{83}$ Humphrey Taylor, Attitudes To Gays and Lesbians Have Become More Accepting, but Most People Still Disapprove of Single-Sex Marriages and Adoption by Same Sex Couples, The HARRIS POLL \#9, Feb. 9, 2000 (reporting the results of a poll of over a thousand adults taken in January 2000), at http://www.harrisinteractive.com/harris_poll/index.asp?PID =1. Similarly, a 1997 poll found that $57 \%$ of Americans were opposed to allowing male couples to adopt children and $55 \%$ were opposed to allowing female couples to do so. Richard Berke, Chasing the Polls on Gay Rights, N.Y. Times, Aug. 2, 1998, § 4 (Week in Review), at 3 .

${ }^{84}$ See, e.g., Alan Yang, Attitudes Towards Homosexuality, 61 PUB. OPINION Q. 477, 479 (1997) ("When asked how they would react if their child told them they were homosexual, large, stable majorities of respondents (over two-thirds) said they would not be accepting and think the relationship with the child would be very much strained or they would be 'very upset.”'); Jeffrey Schmalz, Poll Finds Even Split on Homosexuality's 
strate that even people who are sympathetic to lesbian and gay rights and who do not think homosexual conduct should be illegal continue to perceive homosexuality as a negative trait. In fact, many parents have taken extreme measures to ensure that their children do not grow up to be lesbians or gay men. ${ }^{85}$

\section{The Closet}

There is a further, related, feature of lesbian and gay existence in the United States that warrants attention: lesbians, gay men, and bisexuals are, in a variety of ways - some subtle, some not-encouraged to keep their sexual orientations secret, that is, "in the closet." The closet is a distinctive, pervasive, and, some have argued, singular feature of lesbian and gay existence. ${ }^{86}$ Its effects are easily underestimated. People remain in the closet who are financially and professionally secure enough to survive the negative ramifications that might follow the disclosure of their homosexuality. They do so despite the energy and emotional stress involved in hiding an important part of their lives from family, friends, neighbors, and coworkers. Even when lesbians and gay men "come out," the closet continues to play a central role in their lives. Since in many contexts people are presumed to be heterosexual, the question of whom to tell about one's homosexuality or bisexuality continually arises. For example, a lesbian whose mail carrier mistakenly asks her about her "sister," who is in actuality her lover, will have to decide whether to "come out" to him. Similarly, lesbians and gay men may find themselves having to worry about protecting the secrets of other lesbians and gay men: an individual may know that her friend is a lesbian without knowing who else knows and whom she wants to know. Some have argued that being obliged by social conventions or the "unwritten rules" of the lesbian and gay community to keep some one else's homosexuality secret is an assault on one's dignity as a gay man or lesbian. ${ }^{87}$

The closet is a social creation, but it is enforced in various ways by laws and judicial decisions. Courts have interpreted laws to construct various social and legal "double binds" for sexual minorities with respect

Cause, N.Y. Times, Mar. 5, 1993, at A14. Even a very recent survey of college students (albeit with a rather small sample size), found that $35 \%$ of those surveyed would have a problem with their son or daughter being gay or lesbian. See Fradella et al., supra note 79, at 33-34

${ }^{85}$ See Timothy Murphy, Redirecting Sexual Orientation: Techniques and Justifications, 29 J. Sex Res. 501 (1992). See generally Edward Stein, Choosing the Sexual Orientation of Children, 12 Bioethics 1 (1998); Stein, supra note 9, at 305-27.

${ }^{86}$ See, e.g., Eve Kosofsky Sedgwick, Epistemology of the Closet (1990).

87 See, e.g., Richard Mohr, Gay Ideas: Outing and Other Controversies 11-49 (1992). See generally Larry Gross, Contested Closets: The Politics and Ethics of OuTING (1993) (discussing the history and ethics of "outing" public figures through journalism). 
to their identities and their expression. ${ }^{88}$ Lesbians and gay men are (implicitly or explicitly) told to keep their sexual orientations secret, while, on the other hand, they are (implicitly or explicitly) told to confess them. Similarly, they are told that their identities are protected (although their behavior may be restricted), while conversely, they are discriminated against in certain contexts even when they keep quiet about their identities.

Consider the case of Joseph Acanfora. ${ }^{89}$ Several weeks after he was hired as a public school teacher, school officials learned Acanfora was gay. Acanfora was thereafter transferred to an administrative position that did not involve any contact with students. After his transfer, Acanfora sued the school system demanding his return to the classroom. He also granted several television and newspaper interviews to discuss his situation.

The trial court held that Acanfora's removal from the classroom was reasonable, especially in light of his interviews, which showed a lack of the sort of propriety teachers ought to show. ${ }^{90}$ The Court of the Appeals for the Fourth Circuit upheld Acanfora's removal but on different grounds. They held that Acanfora's interviews concerned "matter[s] of public interest," including the difficulties that homosexuals encounter in families, employment, and the community at large. His speech in these contexts was, therefore, protected under the First Amendment and did not "justify ... the action taken by the school system." 91 The court nevertheless found that Acanfora's removal was justified because he lied to school officials by withholding the information that, in college, he had been involved in a "homophile" organization that "had as its purpose the development of public understanding about homosexuality." 92 Although the school officials admitted that they would have refused to hire Acanfora on the basis of his membership in such an organization, the Fourth Circuit found that his failure to mention his membership in this organization disqualified him from challenging his dismissal. The trial court justified Acanfora's removal from the classroom because he was open about his homosexuality, while the appellate court justified his removal because he kept it secret.

To make matters more complex, consider two other court rulings about homosexuality and public school teachers. In National Gay Task Force v. Board of Education of Oklahoma City, ${ }^{93}$ the Court of Appeals for

${ }^{88}$ SEDGWICK, supra note 86.

${ }^{89}$ Acanfora v. Bd. of Educ. of Montgomery County, 491 F.2d 498 (4th Cir. 1974).

${ }^{90}$ Acanfora v. Bd. of Educ. of Montgomery County, 359 F. Supp. 843, 856-57 (D. Md. 1973), aff'd, 491 F.2d 498 (4th Cir. 1974).

${ }^{91}$ Acanfora, 491 F.2d at 500-01.

${ }^{92}$ Id. at 501 .

93729 F.2d 1270 (10th Cir. 1984), aff'd by an equally divided court, 470 U.S. 903 (1985); see also Aumiller v. Univ. of Del., 434 F. Supp. 1273 (D. Del. 1977) (holding that a teacher may not be fired for speaking out on homosexuality when such speech is not 
the Tenth Circuit held that, under Brandenburg v. Ohio, ${ }^{94}$ a teacher cannot be fired for advocacy of homosexual activity (for example, advocacy of same-sex sodomy, which was at the time illegal in Oklahoma), although a teacher can be fired for public homosexual activity. Contrast this holding with Rowland v. Mad River Local School District,${ }^{95}$ decided by the Court of Appeals for the Sixth Circuit in the same year as National Gay Task Force. In Rowland, a guidance counselor was suspended and subsequently not rehired when she told a secretary, an assistant principal, and several teachers that she was bisexual and involved in a relationship with another woman. The district court found that Rowland's firing violated her freedom of speech. ${ }^{96}$ The Sixth Circuit reversed, holding that Rowland's speech did not involve "a matter of public concern." ${ }^{97}$ According to the Fourth Circuit, Acanfora's homosexuality is a matter of public concern; but according to the Sixth Circuit, Rowland's bisexuality is not.

Given such a tangle of rulings, what was a gay teacher supposed to do after 1985? In this situation and others like it, lesbians, gay men, and bisexuals find themselves in a "double bind." ${ }^{98}$ Although the situation for lesbian and gay teachers may have improved ${ }^{99}$ the closet has continuing vitality in our culture.

For example, the current law regarding lesbians and gay men in the United States Armed Forces reads, in relevant part:

A member of the armed forces shall be separated from the armed forces ... if one or more of the following findings is made and approved in accordance with procedures set forth in such regulations:

(1) That the member has engaged in, attempted to engage in, or solicited another to engage in a homosexual act or acts unless there are further findings ... that the member has demonstrated that-

(A) such conduct is a departure from the member's usual and customary behavior;

intended to generate publicity).

94395 U.S. 444, 449 (1969) (holding that, under the First and Fourteenth Amendments, the mere advocacy of illegal activity may not be criminalized).

95730 F.2d 444 (6th Cir. 1984).

${ }^{96} I d$. at 456-60 (appendix to appellate decision that contains the special verdicts of the district court).

${ }^{97}$ Id. at 449.

${ }^{98}$ William N. Eskridge, Jr. \& Nan D. Hunter, Sexuality, Gender and the Law 629 (1997).

${ }^{99}$ See, e.g., Glover v. Williamsburg Local Sch. Dist. Bd. of Educ., 20 F. Supp. 2d 1160 (S.D. Ohio 1998) (holding that the decision not to renew a gay teacher's contract was motivated by animus and thus violated equal protection); Weaver v. Nebo Sch. Dist., 29 F. Supp. 2d 1279 (D. Utah 1998) (holding that the removal of a lesbian volleyball coach based on her sexual orientation violated equal protection). 
(B) such conduct, under all the circumstances, is unlikely to recur;

(C) such conduct was not accomplished by use of force, coercion, or intimidation;

(D) under the particular circumstances of the case, the member's continued presence in the armed forces is consistent with the interest of the armed forces in proper discipline, good order, and morale; and

(E) the member does not have a propensity or intent to engage in homosexual acts.

(2) That the member has stated that he or she is a homosexual or bisexual, or words to that effect, unless there is a further finding ... that the member has demonstrated that he or she is not a person who engages in, attempts to engage in, has a propensity to engage in, or intends to engage in homosexual acts.

(3) That the member has married or attempted to marry a person known to be of the same biological sex. ${ }^{100}$

Within months of the codification of this policy, the Department of Defense issued various regulations for implementing this policy. ${ }^{101}$ According to these regulations, the military may not ordinarily inquire into or investigate a service member's sexual orientation unless there is "credible information that there is a basis for a discharge." ${ }^{102}$ However, if there is any indication of homosexual activity, or actions or speech that indicate a propensity to engage in such activity, the service member may be discharged. Various federal appellate courts have upheld the constitutionality of this policy. ${ }^{103}$ Given the relative weakness of First Amendment protections in the military context, military policies restricting speech of service members are usually upheld. ${ }^{104}$ In particular, several courts have

10010 U.S.C. $\S 654$ (b) (2000).

${ }^{101}$ See, e.g., Qualification Standards for Enlistment, Appointment, and Induction, Dep't of Def. Directive No. 1304.26 (effective Feb. 5, 1994); Enlisted Administrative Separations, Dep't of Def. Directive No. 1332.14 (effective Feb. 5, 1994) [hereinafter Directive No. 1332.14]; Separation of Regular Commissioned Officers, Dep't of Def. Directive No. 1332.30 (effective Feb. 5, 1994).

${ }^{102}$ Directive No. 1332.14, supra note 101, encl. 3, attach. 4, § 1.1.1 (specifying "Guidelines for Fact-Finding Inquiries into Homosexual Conduct").

${ }^{103}$ See, e.g., Holmes v. Cal. Army Nat'l Guard, 124 F.3d 1126 (9th Cir. 1997); Able v. United States, 88 F.3d 1280 (2d Cir. 1996); Thomasson v. Perry, 80 F.3d 915 (4th Cir. 1996); Richenberg v. Perry, 97 F.3d 256 (8th Cir. 1996).

${ }^{104}$ Although courts widely cite Chief Justice Warren's admonition that "our citizens in uniform may not be stripped of basic rights simply because they have doffed their civilian clothes," see, e.g., Chappell v. Wallace, 462 U.S. 296, 304 (1983) (quoting Earl Warren, The Bill of Rights and the Military, 37 N.Y.U. L. REv. 181, 188 (1962)), often they do not seem to heed it. For example, the Supreme Court held that the Air Force may prevent a 
held that the restrictions on speech involved in the military's policy on homosexuality are justified because they are closely related to a strong governmental interest. ${ }^{105}$ The military's policy concerning homosexuality makes the military an especially difficult environment for lesbians and gay men; a single utterance by a service member suggesting that he or she is gay or lesbian may result in his or her discharge. ${ }^{106}$ Under this policy, lesbians and gay men in the military live in a legally enforced closet. ${ }^{107}$

Lest one think that the legal closet is a relic of the past or an eccentricity of the military, it is worth reviewing the case of Shahar v. Bowers. ${ }^{108}$ In 1990, Robin Shahar was offered a position working for the Attorney General of the State of Georgia, Michael Bowers (of Bowers v. Hardwick fame). On her application for the job, Shahar listed her marital status as "engaged" and indicated that her future spouse was a woman. Before she began working, Shahar and her partner held a ceremony in which they exchanged vows and rings. They also openly changed their last names to Shahar, obtained the married rate on their insurance, and openly cohabited. Bowers claimed that, in light of their public ceremony, which Shahar herself called a wedding, he withdrew his offer of employment to Shahar because her employment would lead to public confusion about the Attorney General's stand on same-sex marriage and other controversial issues. A divided en banc panel of the Court of Appeals for the Eleventh Circuit held that the withdrawal of Shahar's employment offer was justified by Bowers' concern about public perception and the internal consequences of having Shahar work in his office. The Court

service member from wearing a yarmulke while on duty and in uniform, Goldman v. Weinberger, 475 U.S. 503 (1986), and that the Army may prohibit political speeches and demonstrations on base. Greer v. Spock, 424 U.S. 828 (1976). For a case in which a service member won a challenge to the military, see McVeigh v. Cohen, 983 F. Supp. 215 (D.D.C. 1998), discussed infra text accompanying notes 114-119.

${ }^{105}$ See, e.g., Thomasson, 80 F.3d at 928; Able, 88 F.3d at 1292.

${ }^{106}$ One district court permanently enjoined the military's policy concerning homosexuality as a violation of principles of free speech, arguing that the policy "burdens speech based solely on its content by subjecting the member to a discharge process [because of speech that states a homosexual orientation] in which the member has only at best a hypothetical chance to escape separation"; the Second Circuit then vacated that decision. Able v. United States, 880 F. Supp. 968, 976 (E.D.N.Y. 1995), vacated, 88 F.3d 1280 (2d Cir. 1996). On remand, the district court again permanently enjoined the military's policy as unconstitutional, this time relying primarily on equal protection grounds; however, that decision was also overruled by the Second Circuit. Able v. United States, 968 F. Supp. 850 (E.D.N.Y. 1997), rev'd, 155 F.3d 628 (2d Cir. 1998). See also infra text accompanying notes $166-171$.

${ }^{107}$ For useful discussions of the military's policy, see JANET E. HaLley, Don'T: A Reader's Guide to the Military's Anti-Gay Policy (1999), Kenji Yoshino, Assimilationist Bias in Equal Protection: The Visibility Presumption and the Case of "Don't Ask, Don't Tell," 108 YALE L.J. 485 (1998), and Tobias Barrington Wolff, Compelled Affirmations, Free Speech, and the U.S. Military's Don't Ask, Don't Tell Policy, 63 Brook. L. REV. 1141 (1997).

${ }^{108} 114$ F.3d 1097 (11th Cir. 1997) (en banc). 
held that, under the Pickering balancing test, ${ }^{109}$ Georgia's interest "as an employer in promoting the efficiency of the Law Department's important public service" outweighed Shahar's First Amendment interests. ${ }^{110}$ If Bowers' rationalization is to be believed, Shahar was refused a job not because of her homosexuality, but for openly engaging in a same-sex wedding ceremony. Apparently, had Shahar remained in the closet, the failure to hire her would have been unconstitutional.

\section{Sexual Minorities and Cyberspace}

In light of the social and legal obstacles facing lesbians and gay men and, in particular, the social structure of the closet, cyberspace is an ideal environment and a "virtual lifeline" 111 for lesbians, gay men, and other sexual minorities. The following three examples illustrate this point.

\section{Emmalyn Rood}

Emmalyn Rood is a teenager who lives in Portland, Oregon. When she was approximately fourteen years old, Emmalyn began to think she might be a lesbian. Emmalyn wanted to understand various issues relating to homosexuality and her own sexual orientation. Afraid that her mother would discover her if she pursued this project at home, Emmalyn turned to her local public library. Among the resources available at this library were computers that provided free access to the Internet. Emmalyn used these computers to visit Web sites providing information about sexuality and to take advantage of interactive modes of cyberspace communication, such as e-mail and chat rooms. Emmalyn was able to find a supportive community in cyberspace to help her embrace her own sexuality and, subsequently, was able to come out as a lesbian, first to herself and then to her family and friends. ${ }^{112}$

\section{Jeffrey}

In the summer of 1999 , when he was $15, \ldots$ Jeffrey $\ldots$ admitted to himself that he was gay. This discovery had been coming on for some time; he had noticed that he felt no attraction to girls and that he became aroused when showering with other

${ }^{109}$ Pickering v. Bd. of Educ., 391 U.S. 563 (1968) (articulating a balancing test whereby a government employee's rights as a citizen to speak on matters of public interest are to be weighed against the government's interest in having employees perform public services).

${ }^{110}$ Shahar, 114 F.3d at 1110.

${ }^{111}$ ACCESS DENIED, supra note 38, at 4.

${ }^{112}$ Petitioner's Complaint for Declaratory and Injunctive Relief at 44-45, Multnomah County Pub. Library v. United States, No. 01-1332 (E.D. Pa. 2001). 
boys after physical education class. But Jeffrey is a devout Southern Baptist, attending church several times each week, where, he says, the pastor seems to make a point of condemning homosexuality. Jeffrey knew of no homosexuals in his high school or in his small town in the heart of the South.... He prayed that his errant feelings were a phase. But as the truth gradually settled over him, ... he became suicidal.... He called a crisis line for gay teenagers, where a counselor suggested he attend a gay support group in a city an hour and a half away. But being 15 , he was too young to drive and afraid to enlist his parents' help in what would surely seem a bizarre and suspicious errand.

It was around this time that Jeffrey first typed the words "gay" and "teen" into a search engine on [his] computer ... and was staggered to find himself in a teeming online gay world, replete with resource centers, articles, advice columns, personals, chat rooms, message boards, porn sites and-most crucially-thousands of closeted and anxious kids like himself. That discovery changed his life. ${ }^{113}$

\section{Timothy McVeigh}

Helen Hajne, the wife of a non-commissioned officer in the Navy, was organizing a toy drive for the children of members of the crew of the ship on which her husband was posted. She had been in contact by e-mail with various individuals, including Senior Chief Timothy McVeigh (no relation to the convicted Oklahoma City bomber) using her America Online (AOL) account. On September 2, 1997, she received an e-mail message through her AOL account concerning the toy drive from "boysrch@aol.com" that was signed "Tim." The evocative e-mail address piqued her interest, so she searched for and read her correspondent's "member profile," an online file containing an AOL user's selfdescription. According to the information in the profile, the sender of the message was "Tim," a person who worked in the military, lived in Hawaii, and who listed his marital status as "gay." The profile also listed the sender's hobbies as "boy watching" and "collecting pics [digitized photographs] of other young studs." Hajne passed the e-mail message and the profile on to her husband; eventually, this information was passed on to the ship's commanding officer. ${ }^{114}$

${ }^{113}$ Egan, supra note 14, at 110, 113.

${ }^{114}$ McVeigh v. Cohen, 983 F. Supp. 215, 217 (D.D.C. 1998). 
Suspecting that the sender of this e-mail was McVeigh and inferring that McVeigh was gay, the ship's legal advisor, a member of the Judge Advocate Generals' Corps, the military's "in-house" legal team, initiated an investigation. A Navy investigator contacted AOL through its technical services department and, without self-identifying as a member of the Navy or as part of an investigation of McVeigh, inquired whether the "boysrch" account in fact belonged to Timothy McVeigh. The customer service representative confirmed that it did.

Twenty days after Hajne received the e-mail message from "Tim," the Navy began discharge proceedings against McVeigh under the "Don't Ask, Don't Tell" policy ${ }^{115}$ because of his "homosexual conduct, as evidenced by [his] statement that [he is] a homosexual." 116 On the ground that McVeigh had engaged in "homosexual conduct"-presumably, this "homosexual conduct" was that he identified himself as gay in his AOL member profile- the Navy scheduled McVeigh for discharge.$^{117}$ Before this occurred, McVeigh filed in federal court for a preliminary injunction to bar his discharge. The court held that the Navy had violated the military's "Don't Ask, Don't Tell" policy by initiating an investigation of McVeigh without sufficient evidence of prohibited behavior and that the Navy had probably also violated a provision of the Electronic Communications Privacy Act of $1986^{118}$ by obtaining information from an online service provider without following the appropriate procedures. ${ }^{119}$

An online news magazine for lesbians and gay men aptly described the importance of cyberspace as follows:

For countless gay men and lesbians across all age groups, the Internet has provided a means of escape from the emotional and social isolation that for so many people is part of being gay. Deeply personal issues of sexual identity could, for the first time, be explored in almost total anonymity without threat of rejection or violence. The medium was embraced early and

11510 U.S.C. $\$ 654$ (b)(2) (2000).

${ }^{116}$ McVeigh, 983 F. Supp. at 217.

${ }^{117} \mathrm{Id}$. at 215 .

11818 U.S.C. $\$ 2703(\mathrm{~b})(1)(\mathrm{A})-(\mathrm{B}),(\mathrm{c})(1)(\mathrm{A})-(\mathrm{D})$ (2000). The statute reads, in part:

A provider of electronic communication service or remote computing service shall disclose a record or other information pertaining to a subscriber to or customer of such service to a governmental entity only when the governmental entity (i) obtains a warrant issued using the procedures described in the Federal Rules of Criminal Procedure or equivalent State warrant; (ii) obtains a court order for such disclosure ... ; (iii) has the consent of the subscriber or customer to such disclosure; or (iv) submits a formal written request relevant to a law enforcement investigation concerning telemarketing fraud for the name, address, and place of business of a subscriber or customer of such provider, which subscriber or customer is engaged in telemarketing.

Id. $\S 2703(\mathrm{c})(1)(\mathrm{B})$.

${ }^{119}$ McVeigh, 983 F. Supp. at 215. 
strongly by gay people and it is widely acknowledged that gay men and lesbians have a presence on the Internet disproportionate to their numbers. ${ }^{120}$

Given the military's intolerance of homosexuality, lesbians and gay men in the military, like McVeigh, are drawn to cyberspace as a way to express and explore their sexual orientations. ${ }^{121}$ Further, cyberspace is especially significant for gay and lesbian teenagers who, like Jeffrey and Emmalyn Rood (before she came out), are living with their families while keeping their sexual orientations a secret, and for whom physically entering the lesbian and gay community may be difficult.

For homosexual teenagers with computer access, the Internet has, quite simply, revolutionized the experience of growing up gay. Isolation and shame persist among gay teenagers, of course, but now, along with the inhospitable families and towns in which many find themselves marooned, there exists a parallel online community-real people like them in cyberspace with whom they can chat, exchange messages and even engage in (online) sex.... What [is] most critical to ... gay kids ... [is] the simple, revelatory discovery that they [are] not alone.

[G]ay teenagers surfing the Net can find Web sites packed with information about homosexuality and about local gay support groups and counseling services, along with coming-out testimonials from young people around the world. Gay pornography, too, can be a valuable resource; [for some youths,] male and female ... the availability of online porn [was] critical to their discovery of their sexual orientation. ${ }^{122}$

In light of the social and legal challenges faced by lesbians, gay men and other sexual minorities-in particular the pervasive institution of the closet-cyberspace is an important refuge for many lesbians and gay men. ${ }^{123}$ This crucial role that cyberspace plays for many sexual minorities

${ }^{120}$ The Data Lounge, Internet Issues, at http://www.datalounge.com/datalounge/issues/ index.html? storyline $=286$ (last visited Nov. 9, 2002). See also DAwson, supra note 14 .

${ }^{121}$ For a Web site devoted to lesbians and gay men in the military, see Servicemen's Legal Defense Network, at http://www.sldn.org (last visited Nov. 9, 2002). Timothy McVeigh's Web site can be found at http://www.geocities.com/Pentagon/9241 (last visited Nov. 9, 2002).

${ }^{122}$ Egan, supra note 14 , at 113.

${ }^{123}$ A possible concern with respect to the claims in this Part stems from a common observation among opponents of lesbian and gay rights: perhaps many of the claims I make about lesbians and gay men are similarly true of pedophiles; that is, pedophiles are also typically closeted and might find cyberspace an important refuge. This argument takes the form of a reductio ad absurdum: clearly the pedophile's speech in cyberspace does not deserve especially close scrutiny, and if the relationship of the pedophile to speech in cyberspace is like that of lesbians and gay men, then the speech of lesbians and gay men in 
explains why lesbians, gay men, and the organizations that represent them are among the plaintiffs who have challenged attempts to regulate speech in cyberspace. In the following Part, I argue, in light of this important function of cyberspace, that attempts to regulate speech in cyberspace should be carefully examined to ensure that they do not suppress the speech of sexual minorities.

\section{Free Speech and Sexual Minorities}

\section{A. Free Speech Generally}

The First Amendment begins, "Congress shall make no law ... abridging the freedom of speech ...." 124 Despite the simplicity and apparent breadth of the protections of speech, the First Amendment is not absolute. The Supreme Court has recognized various exceptions to and limitations on the protection of speech, with respect to both type of expression (for example, obscene speech, ${ }^{125}$ libel, ${ }^{126}$ and the advocacy of violence ${ }^{127}$ ) and context (for example, in certain broadcast media, ${ }^{128}$ certain public fora, ${ }^{129}$ and in the context of military employment ${ }^{130}$ ). Speech may be restricted when it is likely to incite imminent lawless action. ${ }^{131}$ Moreover, the Supreme Court has held that non-obscene but nonetheless "indecent" speech can be regulated in the context of broadcast media. ${ }^{132}$ The Court has essentially established a hierarchy within protected

cyberspace also does not deserve close scrutiny. This objection does not constitute a serious challenge to the arguments advocated in this Article. The distinctive problem with a pedophile's use of cyberspace is that he will use it to arrange sexual encounters with children -encounters that are illegal and often non-consensual and, hence, immoral. See, e.g., Donald S. Yamagami, Prosecuting Cyber-Pedophiles: How Can Intent Be Shown in a Virtual World in Light of the Fantasy Defense, 41 Santa Clara L. Rev. 547 (2001). A thorough articulation of this false analogy between pedophiles' speech in cyberspace and the speech of gay men and lesbians in cyberspace is beyond the scope of this Article.

${ }^{124}$ U.S. Const. amend. I. The Supreme Court has held that the Due Process Clause of the Fourteenth Amendment extends this prohibition on the abridgement of the freedom of speech to states as well. See, e.g., Young v. Am. Mini Theatres, Inc., 427 U.S. 50, 52 n.1 (1976); Thornhill v. Alabama, 310 U.S. 88, 95 (1940); Gitlow v. New York, 268 U.S. 652, 666 (1925).

${ }^{125}$ Roth v. United States, 354 U.S. 476 (1957).

${ }^{126}$ N.Y. Times Co. v. Sullivan, 376 U.S. 254 (1964).

${ }^{127}$ Brandenburg v. Ohio, 395 U.S. 444 (1969).

${ }^{128}$ FCC v. Pacifica Found., 438 U.S. 726 (1978).

${ }^{129}$ Connick v. Myers, 461 U.S. 138 (1983) (holding that a government employee may be discharged for private speech that interferes with government services); Bethel Sch. Dist. v. Fraser, 478 U.S. 675 (1981) (holding that a school may prohibit a student from giving a sexually explicit speech at a school assembly).

${ }^{130}$ See, e.g., Goldman v. Weinberger, 475 U.S. 503 (1986); Greer v. Spock, 424 U.S. 828 (1976).

${ }^{131}$ See, e.g., Brandenburg, 395 U.S. at 447; Chaplinsky v. New Hampshire, 315 U.S. 568 (1942).

${ }^{132}$ FCC v. Pacifica, 438 U.S. at 726 . The Court specifically considered the "seven dirty words" listed in George Carlin's comedy routine: shit, piss, fuck, cunt, cocksucker, motherfucker, and tits. 
speech: some speech, such as speech concerning matters of contemporary political concern, ${ }^{133}$ receives very strong protection, and any attempt to regulate it will be strictly scrutinized; other speech, such as indecent speech and commercial speech, ${ }^{134}$ may receive limited First Amendment protection in certain contexts.

Constitutional theorists have offered various justifications for the freedom of speech. Among the most prominent are that free speech encourages and protects the robust public debate necessary for democracy, ${ }^{135}$ that it advances knowledge, ${ }^{136}$ and that it promotes and ensures individual autonomy. ${ }^{137}$ Various scholars have criticized each of these theoretical justifications. Depending on which justification for free speech one embraces, one might have a different account of which types of speech deserve First Amendment protection. The Court has not consistently endorsed any single approach, and has in fact often cited multiple theories in the same opinion.

\section{B. The Speech of Sexual Minorities}

The speech of lesbians, gay men, and other sexual minorities has received varying treatment over the course of this century, and its status remains unclear today. Until 1958 , speech that had a "tendency to corrupt morals" was deemed obscene. The decision of the Court of Appeals for the Ninth Circuit in One, Inc. v. Olesen illustrates how courts typically applied the corruption-of-morals test to speech relating to homosexuality. ${ }^{138}$ One was perhaps the first gay and lesbian magazine (although the publishers and readers of One would not have used that phrase to describe it). ${ }^{139}$ A copy of an issue of One was confiscated under a statute prohibiting the use of the Post Office to transmit obscene publications. ${ }^{140}$ Applying the corruption-of-morals test, the Ninth Circuit held that the magazine was obscene and that the Post Office could not deliver it. In

${ }^{133}$ See, e.g., Alexander Meiklejohn, Free Speech and Its Relation to SelfGovernment (1948); Owen Fiss, Liberalism Divided: Freedom of Speech and the Many Uses of State Power (1996).

${ }^{134}$ See, e.g., Va. State Bd. of Pharmacy v. Va. Citizens Consumer Council, Inc., 425 U.S. 748 (1976) (holding that commercial speech is protected by the First Amendment but that it receives somewhat weaker protection than most other types of speech).

${ }^{135}$ See, e.g., N.Y. Times Co. v. Sullivan, 376 U.S. 254 (1964); MEIKLEJOHN, supra note 133; Fiss, supra note 133.

${ }_{136}$ See, e.g., John Stuart Mill, On Liberty (Stefan Collini ed., Cambridge Univ. Press 1989) (1859); Abrams v. United States, 250 U.S. 616, 630 (1919) (Holmes, J., dissenting); Whitney v. California, 274 U.S. 357, 375 (Brandeis, J., concurring).

${ }^{137}$ See, e.g., Whitney, 274 U.S. at 375 (Brandeis, J., concurring); Timothy Scanlon, A Theory of Freedom of Expression, 1 PHIL. \& PuB. AfF. 204 (1972).

${ }_{138} 241$ F.2d 772 (9th Cir. 1957), rev'd per curiam, 355 U.S. 371 (1958).

${ }^{139}$ See ESKRIDGE \& HUNTER, supra note 98, at 411.

${ }^{140} 18$ U.S.C. $\$ 1461$ (2000) (prohibiting the mailing of any "obscene, lewd, lascivious, or filthy book, pamphlet, picture, paper, letter, writing, print, or other publication of indecent character"). 
deciding to censor One, the Ninth Circuit focused in particular on a story describing a young woman who was coming to grips with her homosexuality (the court deemed this story "cheap pornography calculated to promote lesbianism"141) and a poem concerning public sex in England (the court considered this poem "dirty, vulgar, and offensive to the moral senses" ${ }^{142}$ ). Discussions and portrayals of homosexuality before 1958 in the United States typically received this sort of judicial treatment. ${ }^{143}$

In 1958, the Supreme Court overturned the Ninth Circuit's decision in Olesen in a one-sentence per curiam ruling, ${ }^{144}$ holding that the magazine was not obscene under the criteria articulated in Roth v. United States. ${ }^{145}$ In Roth, the Supreme Court explicitly held that obscene material is not protected speech. The Court defined obscene material as that which "deals with sex in a manner appealing to prurient interest," 146 and it defined "material that appeals to prurient interest" as material "having a tendency to excite lustful thoughts." ${ }^{147}$ The majority went on to explain that "sex and obscenity are not synonymous." 148 Rather, they found that the First Amendment crucially protects " $[t]$ he portrayal of sex . . in art, literature and scientific works." 149 The Court provided no explanation for its decision in Olesen, but it presumably understood the publication to fall within one of these categories.

The test for obscenity developed in Roth has been modified over time. In Miller v. California, ${ }^{150}$ the Court articulated the test for obscene speech as:

(a) whether "the average person, applying contemporary community standards" would find that the work, taken as a whole, appeals to the prurient interest,

(b) whether the work depicts or describes, in a patently offensive way, sexual conduct specifically defined by ... state law, and

(c) whether the work, taken as a whole, lacks serious literary, artistic, political, or scientific value. ${ }^{151}$

${ }^{141}$ Olesen, 241 F.2d at 777.

${ }^{142} \mathrm{Id}$.

${ }^{143}$ See generally William Eskridge, Gaylaw: Challenging the Apartheid of THe Closet 57-97 (1999).

144 Olesen, 355 U.S. at 371.

145354 U.S. 476 (1957).

${ }^{146} \mathrm{Id}$. at 487.

${ }^{147}$ Id. at 487 n. 20.

${ }^{148} \mathrm{Id}$. at 487.

${ }^{149} \mathrm{Id}$.

150413 U.S. 15 (1973).

${ }^{151} I d$. at 24 (internal citation omitted). 
Following this test, much speech concerning homosexuality has been held to be deserving of First Amendment protection. Recall, for example, National Gay Task Force, in which the Tenth Circuit held that a public employee may not be fired for advocating or promoting homosexual conduct. ${ }^{152}$ Similarly, in Van Ooteghem v. Gray, the Court of Appeals for the Fifth Circuit held that a public employee could not be fired for speaking publicly in favor of civil rights for lesbians and gay men. ${ }^{153}$

There are, however, some limitations on the protection of gay men and lesbians' speech that are distinct from general constraints on free speech. For example, in Singer v. U.S. Civil Service, the Court of Appeals for the Ninth Circuit held that it did not violate the First Amendment for a public employee to be fired for "openly and publicly flaunting his homosexual way of life." ${ }^{54}$ The Ninth Circuit reasoned that although speech concerning homosexuality was protected in some cases, this protection did not extend to "open and public flaunting or advocacy of homosexual conduct." 155 Although Singer was vacated by the Supreme Court after new Civil Service regulations were developed, ${ }^{156}$ some courts continued to cite the Ninth Circuit's holding in Singer for the principle that while public employees may not be subject to penalties because of their homosexuality, they may be penalized for being open about their homosexuality. ${ }^{157}$ The more recent cases of Rowland ${ }^{158}$ and Shahar ${ }^{159}$ can be understood as fitting roughly into the Singer paradigm. Neither Rowland nor

${ }^{152}$ Nat'l Gay Task Force v. Bd. of Educ. of Oklahoma City, 729 F.2d 1270 (10th Cir. 1984), affirmed by an equally divided court, 470 U.S. 903 (1985).

${ }^{153}$ Van Ooteghem v. Gray, 654 F.2d 304 (5th Cir. Aug. 1981) (en banc) (per curiam).

${ }^{154}$ Singer v. United States Civil Serv. Comm'n, 530 F.2d 247, 255 (9th Cir. 1976) (citation omitted), vacated, 429 U.S. 1034 (1977); see also McConnell v. Anderson, 451 F.2d 193 (1971).

155 Singer, 530 F.2d at 256.

${ }^{156}$ Singer v. United States Civil Serv. Comm'n, 429 U.S. 1034 (1977), vacating 530 F.2d 247 (9th Cir. 1971). A new personnel manual was developed on December 21, 1973, and new regulations became effective on July 2, 1975. Office of Personnel Management Civil Service Regulations, 5 C.F.R. § 731.202 (1976). The manual was modified in light of the decision in Society for Individual Rights v. Hampton, 63 F.R.D. 399 (N.D. Cal. 1973) (holding that the government must stop discharging homosexuals "solely" because the employment of such a person might result in public contempt of the government and thereby reduce confidence in government), aff'd in part, 528 F.2d 905 (9th Cir. 1975). On procedural grounds, the Ninth Circuit did not consider these changes because the new personnel manual was not part of the record before the district court and the new regulations were adopted after the judgment of the district court. Singer, 530 F.2d at 255 . The Supreme Court, at the suggestion of the Solicitor General, remanded the case to the Civil Service Commission for consideration in light of the new regulations. Ultimately, the Federal Employee Appeals Authority dismissed the case against Singer. For further discussion of these proceedings, see Aumiller v. Univ. of Del., 434 F. Supp. 1273, 1294 (D. Del. 1977); Rhonda Rivera, Sexual Preference Law, 30 DraKe L. Rev. 317 (1980-1981).

${ }^{157}$ See, e.g., Beller v. Middendorf, 632 F.2d 788, 808 n.20 (9th Cir. 1980); Childers v. Dallas Police Dep't, 513 F. Supp. 134, 141-42 (N.D. Tex. 1981) (denying a city employee promotional opportunities because he was not discreet about his homosexuality), aff' $d, 669$ F.2d 732 (5th Cir. 1982).

${ }^{158}$ Rowland v. Mad River Local Sch. Dist., 730 F.2d 444 (6th Cir. 1984).

${ }^{159}$ Shahar v. Bowers, 114 F.3d 1097 (11th Cir. 1997) (en banc). 
Shahar lost her job because of sexual orientation per se. Rowland was fired because of her private speech (telling some of her co-workers that she was bisexual). ${ }^{160}$ Shahar was not hired because of her "expressive conduct" (having a public wedding with another woman). ${ }^{161}$ In a similar vein, the Supreme Court effectively validated the decision made by organizers of the St. Patrick's Day parade in Boston to prohibit lesbians and gay men from marching in the parade carrying signs identifying themselves as Irish lesbians and gay men. ${ }^{162}$

Additionally, the military's policy concerning homosexuality ${ }^{163}$ is akin to the Singer paradigm in restricting the speech of lesbians and gay men. There is a seemingly straightforward argument that this policy violates free speech: a service member faces strong sanctions for making a statement such as, "I am gay," or "I am a lesbian." Although such speech ostensibly does not lead automatically to the service member's discharge from the military, ${ }^{164}$ it does create a strong but rebuttable presumption that the service member is likely to violate the law against homosexual conduct. ${ }^{165}$

District Judge Eugene Nickerson held that this aspect of the military's policy concerning homosexuality violated the First Amendment. ${ }^{166}$ Nickerson noted that lesbian and gay service members who make statements about their sexual orientation are making statements that deserve the strongest protection of the First Amendment; ${ }^{167}$ their "coming out" statements constitute "important speech" because they are "expression[s] of personal dignity and integrity." 168 As such, the government may regulate such speech only if the regulation "promotes a compelling interest" through use of "the least restrictive means." 169 After a discussion of the military policy and its justifications, Nickerson concluded that "under the First Amendment a mere statement of homosexual orientation is not

${ }^{160}$ See Rowland, 730 F.2d at 446.

${ }^{161}$ See Shahar, 114 F.3d at $1100-01$.

${ }^{162}$ Hurley v. Irish-Am. Gay, Lesbian \& Bisexual Group of Boston, Inc., 515 U.S. 557, 572 (1995) (holding that parade organizers had a free speech right not to be compelled to include openly lesbian and gay Irish people in their parade). For discussion of Hurley, see infra text accompanying notes 258-261; see also Darren Lenard Hutchinson, Accommodating Outness: Hurley, Free Speech, and Gay and Lesbian Equality, 1 U. PA. J. Const. L. 85 (1998).

${ }^{163} 10$ U.S.C. $§ 654$ (2000); see also supra notes 100-106 and accompanying text.

${ }^{164}$ In many cases, like McVeigh's, the military violates its own policy. See McVeigh v. Cohen, 983 F. Supp. 215 (D.D.C. 1998); see also Stacey L. Sobel et al., Conduct UNbecoming: The Sixth Annual Report on "Don't Ask, Don't Tell, Don't Pursue" (2000), available at http://www.sldn.org/templates/law/record.html?section=22\&record= 21.

${ }^{165} 10$ U.S.C. $\S 654$ (2000).

${ }^{166}$ Able v. United States, 880 F. Supp. 968 (E.D.N.Y. 1995), vacated, 88 F.3d 1280 (2d Cir. 1996).

${ }^{167} \mathrm{I}$ argue that this conclusion should be applied to lesbians and gay men in general, not just to gay and lesbian service members. See infra Part VII.

${ }^{168}$ Able, 880 F. Supp. at 973.

${ }^{169} \mathrm{Id}$. 
sufficient proof of intent to commit acts as to justify the initiation of discharge proceedings." 170 The Court of Appeals for the Second Circuit overturned Nickerson's decision, ${ }^{171}$ applying a more deferential First Amendment standard. Under this weaker test, the military's policy satisfied the compelling interest and least restrictive means tests. ${ }^{172}$

In sum, although lesbians and gay men and their speech are protected by the First Amendment, courts have found that these protections are subject to various limitations. In particular, the social and legal construct of the closet interacts with the free speech rights of lesbians and gay men in inconsistent ways. Although lesbians and gay men are genderally free to speak about their sexual orientations, lesbian and gay rights, and other issues of interest and concern to them, their speech remains subject to some state and social sanctions. Neither speaking as a gay man or lesbian nor speaking about homosexuality is without negative ramifications, especially in comparison to speaking about heterosexual relationships, heterosexual lifestyles, and heterosexual sex.

\section{ANONYMous SPEECH}

\section{A. Theoretical Perspectives on Anonymous Speech}

\section{Arguments in Favor of Protecting Anonymous Speech}

Perhaps the most significant argument made by both courts and scholars in favor of protecting anonymous speech is that anonymity contributes to the type of public debate that is central to a democracy. ${ }^{173}$ Anonymity encourages people to freely express their views. If a person must identify herself in order to express an opinion, unpopular opinions are less likely to be expressed. The expression of a multiplicity of viewpoints, especially controversial ones, is crucial to sustaining a vibrant democratic nation. Measures must be taken to ensure that people are willing to express their views, particularly with respect to matters of political controversy or of significance to the general public. The desire for a robust public debate on important matters of political concern supports the protection of anonymous speech.

If anonymity facilitates the expression of unpopular viewpoints, it is possible to understand the failure to protect anonymous speech as an im-

${ }^{170} \mathrm{Id}$. at 976.

${ }^{171}$ Able v. United States, 88 F.3d 1280 (2d Cir. 1996).

172 Id. at 1296.

${ }^{173}$ See, e.g., Anne Wells Branscomb, Anonymity, Autonomy, and Accountability: Challenges to the First Amendment in Cyberspaces, 104 YALE L.J. 1639 (1995); Amy Constantine, What's in a Name? McIntyre v. Ohio Elections Commission: An Examination of the Protection Afforded Free Speech, 29 ConN. L. Rev. 459 (1996); Lee Tien, Who's Afraid of Anonymous Speech? McIntyre and the Internet, 75 OR. L. REV. 117 (1996); see also infra text accompanying notes 186-212 (discussing cases). 
plicitly content-based restriction on speech. The Supreme Court has articulated different standards for evaluating laws that involve contentbased restrictions as compared to those that involve content-neutral restrictions. The most suspect type of content-based restrictions entails restriction of speech based on the view it expresses, or viewpoint discrimination. Consider, for example, Kingsley International Pictures Corp. v. Regents of the University of New York. ${ }^{174}$ A state licensing law prohibited the showing of films that involved the positive portrayal of "acts of sexual immorality." On this basis, the state withheld a license from the film "Lady Chatterley's Lover," which intimated that adultery may be morally permissible under some circumstances. The Supreme Court overturned the law because it prohibited speech on the basis of viewpoint; the "very heart" of the First Amendment is that its protection is not "confined to the expression of ideas that are conventional or shared by a majority." 175

The prohibition on content-based discrimination, reaffirmed in R.A.V. v. City of St. Paul, ${ }^{176}$ can be understood as justifying the protection of anonymous speech. If anonymous speech is not protected, then people who hold unpopular opinions on matters of controversy will, in some cases, withhold their expression of these opinions. By contrast, people who hold popular opinions will not similarly withhold their speech. As a result, the expression of unpopular viewpoints will be restricted in violation of the First Amendment.

Protections for anonymous speech can also be linked with the right to privacy. In a line of cases from Griswold v. Connecticut ${ }^{177}$ to Roe v. Wade, ${ }^{178}$ the Court has articulated a right to privacy-a right to freedom from state interference in certain aspects of one's life. If the First Amendment protects the right to speak publicly and to participate in discussions of matters of political concern, the right to privacy protects one's right to speak without undermining her privacy. If the central goal of the First Amendment is robust public debate, the state should remove barriers from active participation. The requirement that a person give up a significant portion of her privacy in order to speak will reduce the scope of debate by decreasing the likelihood that certain people will participate in public discussions.

Anonymous speech can be similarly defended with respect to alternative justifications of the right to free speech. The expression of un-

174360 U.S. 684 (1959).

${ }^{175}$ Id. at $688-89$.

176505 U.S. 377 (1992); see infra text accompanying notes 252-254.

177381 U.S. 479 (1965) (holding that the right to privacy includes the right of married couples to purchase contraceptives).

178410 U.S. 113 (1973) (holding that the right to privacy includes a woman's right to an abortion). 
popular views is important to attaining truth in science ${ }^{179}$ and philosophy ${ }^{180}$ as well as politics. If free speech is crucial to the quest for truth in the "market place of ideas," 181 then anonymous speech is worthy of protection because it ensures the expression of multiple viewpoints.

\section{Arguments Against Protecting Anonymous Speech}

There are, however, various arguments against protecting anonymous speech. One particularly strong argument made by commentators and judges is that anonymity undermines accountability, ${ }^{182}$ which prevents crime and ensures responsible contributions to public debate. An anonymous speaker faces no consequences for speaking carelessly, callously, or even criminally. With respect to accountability, there are two potential repercussions of anonymity that are cause for concern: first, that anonymity will lead to crime; and second, that anonymity will undermine free speech rather than advance it. I consider these possibilities in turn.

In Plato's Republic, while discussing what makes a person just, Socrates relates the tale of a ring that enabled its wearer to become invisible on demand. ${ }^{183}$ Gyges used this ring, the story goes, to seduce the queen, kill the king, and usurp his power. The power of invisibility brought out the true nature of Gyges: in the absence of accountability, Gyges' true and unjust nature was expressed. Unfortunately, anonymity carries a similar potential for abuse. A truly anonymous speaker can libel, slander, and defame at will. Once the state grants a broad right to anonymity, there is little it can do to prevent people from abusing the power of anonymous speech. The resulting possibility of harmful or even criminal speech is a strong argument against protecting anonymity.

Anonymity will also, say its critics, undermine rather than improve public debate on important issues. A person who contributes to public debate anonymously lacks accountability and therefore reliability. Without knowing who a speaker is, what her biases are, or where her expertise lies, the audience cannot evaluate the speaker's contributions to public debate. As a result, anonymity creates a greater potential for deception

${ }^{179}$ Paul Feyerabend, Against Method (Verso 1988) (1975) (arguing that the best strategy for science is "anything goes").

${ }^{180}$ Bertrand Russell, The Problems of Philosophy (1965) (arguing that philosophy tries to "overthrow the tyranny of custom" and that doing so involves considering a wide range of viewpoints, even the most unpopular).

${ }^{181}$ E.g., Comment, The Constitutional Right to Anonymity: Free Speech, Disclosure, and the Devil, 70 YALE L.J. 1084 (1961).

${ }^{182}$ See, e.g., Mark Whitt, McIntyre v. Ohio Elections Comm'n: "A Whole New Boutique of Wonderful First Amendment Litigation Opens Its Doors," 29 AKron L. Rev. 423 (1996); Note, Bans on Anonymous Political Leafletting, 109 Harv. L. Rev. 111, 180-90 (1995); see also infra text accompanying notes 193-195 and 203-207 (discussing dissenting opinions).

${ }^{183}$ Plato, Republic, (Paul Shorey trans.) in 2 Collected Dialogues 607 (Edith Hamilton \& Huntington Cairns eds., Princeton Univ. Press 1982). 
and frivolity in public debate. Relatedly, the possibility of anonymous contributions to public debate may lead more people to feel the need to be anonymous. In other words, anonymity breeds more anonymity.

Critics of anonymity might also argue that it is possible to protect unpopular minorities without granting general protections for anonymity. The state permits and/or provides anonymity when it is necessary to do so. Examples include the occasional practice of masking speakers' identity on television news and talk shows as well as the witness protection program. These exceptions suggest that anonymity can be selectively provided to people who truly need it in order to safely contribute to public discussion. ${ }^{184}$

Finally, anonymity undermines the role that free speech plays in contributing to individual speakers' autonomy and sense of self. A person who can only comfortably contribute to public debate by speaking anonymously presumably feels unsafe in relation to society at large. There seems to be intrinsic value to speaking openly for and as oneself. Speaking through the veil of anonymity undermines the role of speech in identity-formation and in one's sense of involvement in a democratic community.

\section{Responses to Arguments Against Anonymity}

Few would argue that the protection of anonymous speech should be absolute. A person who commits a crime under the cloak of anonymity may thereby surrender her claim to anonymity. The state is thus entitled to try to identify and punish those who use anonymity to commit a crime. In general, it is possible to strike a workable balance between the need for anonymity and the prevention of crime.

Further, anonymity does not in fact undermine public discourse. People involved in public debate ultimately have to evaluate claims and arguments independently of the people who made them. In evaluating claims, a reader can check the facts, ponder and discuss the arguments, and turn to people she knows for help. As a New York state court cautioned in a 1978 case involving anonymous political speech:

Don't underestimate the common man. People are intelligent enough to evaluate the source of anonymous writing. They can see it is anonymous .... They can evaluate its anonymity along with its message. ... [O]nce they have done so, it is for them to

${ }^{184}$ For further elaboration of this argument against the need for general protections for anonymity, see the discussion of Brown v. Socialist Workers '74 Campaign Comm., 459 U.S. 87 (1982), infra text accompanying note 221. 
decide what is responsible, what is valuable and what is the truth. ${ }^{185}$

Finally, if the power to determine who "needs" to be anonymous resides with the state (as it does with the witness protection program), people will be less likely to express views that are critical of the state. To receive a grant of anonymity from the state, a person would have to reveal herself to the state bureaucracy. Sometimes, however, the state itself may be the source of a person's need to remain anonymous. For anonymity to empower people with unpopular views to speak, the decision to be anonymous should reside in those people, not in the state.

\section{B. Supreme Court Doctrine}

Three Supreme Court cases have held that the First Amendment guarantee of free speech includes strong protection for anonymous speech, relying, in part, on the theoretical arguments in favor of protecting anonymous speech. ${ }^{186}$ Talley $v$. California concerned a Los Angeles municipal ordinance prohibiting the distribution of anonymous handbills. ${ }^{187}$ Los Angeles justified its ordinance by claiming that it legitimately aimed at preventing fraud, libel and false advertising. Justice Black, writing for a six-Justice majority, overturned the ordinance, arguing that the requirement that the author of a distributed handbill must be identified on the handbill "would tend to restrict ... freedom of expression" 188 and finding the ordinance to be broader than necessary to fulfill its legitimate aims. ${ }^{189}$ Further, the Court observed that anonymity is often used for the "most constructive purposes," 190 not simply for the nefarious purposes that Los Angeles sought to prevent. The Court noted that "[p]ersecuted groups and sects from time to time throughout history have been able to criticize oppressive practices and laws either anonymously or not at all." 191 The Court offered the examples of religious minorities in England and the Founding Fathers who authored The Federalist Papers;

${ }^{185}$ People v. Duryea, 351 N.Y.S.2d 978, 996 (N.Y. Sup. Ct.) (quoted by McIntyre v. Ohio Election Comm'n, 514 U.S. 334, 348 n.11 (1995)), aff'd, 354 N.Y.S.2d 663 (N.Y. App. Div. 1974).

${ }^{186}$ Buckley v. Am. Constitutional Law Found., 525 U.S. 182 (1999); McIntyre v. Ohio Election Comm'n, 514 U.S. 334 (1995); Talley v. California, 362 U.S. 60 (1960). Most recently, the Court reaffirmed McIntyre and Buckley in Watchtower Bible \& Tract Society of New York, Inc. v. Village of Stratton, 122 S. Ct. 2080 (2002).

187 The Los Angeles ordinance at issue provided, "No person shall distribute any handbill in any place under any circumstances, which does not have printed on the cover, or the face thereof, the name and address" of the people who wrote (or printed) and distributed the handbill. Talley, 362 U.S. at 60-61 (quoting L.A. Municipal CodE $\$ 28.01$ (1960)).

${ }^{188} I d$. at 64 .

${ }^{189} \mathrm{Id}$. at 65 .

${ }^{190} \mathrm{Id}$.

${ }^{191} \mathrm{Id}$. at 64 . 
in both cases, people wrote anonymously or pseudonymously with positive results. ${ }^{192}$ The Talley Court relied in particular on the idea that anonymity protects unpopular minorities and the benefits of free speech to a democracy.

Justice Clark, writing for the dissent, argued that "the Constitution say[s] nothing about the freedom of anonymous speech." 193 The ordinance at issue in Talley, he said, had the legitimate purpose of preventing fraud, libel, and other crimes. The ordinance, according to the dissent, was constitutionally legitimate in that it only requires a person "who exercises his right to free speech through writing or distributing handbills [to] identify himself just as does one who speaks from the platform." 194 The dissent argued that Talley had made no showing that he would have suffered any injury or restraint on his freedom of speech if he had followed the ordinance by identifying himself on the handbill. ${ }^{195}$ The dissent would have allowed the ordinance to stand because it had a legitimate purpose, it in no way infringed upon a constitutionally protected right, and, as applied, it did not cause any harm to the plaintiff. The Talley dissent thus appealed to the importance of accountability and emphasized that anonymity should be granted only when necessary.

In McIntyre v. Ohio Election Commission, the Court reaffirmed Talley. ${ }^{196}$ McIntyre concerned an Ohio law against anonymous election leaflets. ${ }^{197}$ Justice Stevens, writing for a six-Justice majority (Justice Thomas concurred only in the judgment), ${ }^{198}$ argued that the prohibition on anonymous leaflets is a direct and impermissible regulation of the content of speech. Anonymity is a rhetorical tool for a writer; a writer's decision to make use of this tool by remaining anonymous is protected by the First Amendment. ${ }^{199}$ The identity of the speaker is a part of a text's content, and prohibiting anonymity is therefore a constitutionally impermissible restriction on content. Further, advocates of unpopular causes are in particularly precarious situations; as a result, their viewpoints are especially burdened by laws restricting anonymous speech. ${ }^{200}$ Anonymity,

${ }^{192} I d$. at 65.

${ }^{193}$ Id. at 70 (Clark, J. dissenting).

${ }^{194} \mathrm{Id}$. at 71 (Clark, J. dissenting).

${ }^{195} \mathrm{Id}$. at 69 (Clark, J. dissenting).

${ }^{196}$ McIntyre v. Ohio Election Comm'n, 514 U.S. 334 (1995).

197 The Ohio statute at issue, OHIO REv. CoDE ANN. § 3599.09(A) (West 1994) (amended and recodified as OHIo Rev. Code ANN. § 3517.20 (West Supp. 2002)), prohibits the writing, printing, posting or distribution of material designed to influence an election "unless there appears on such form or publication ... the name and residence of [an officer] ... of the organization ... or the person who issues" the material.

${ }^{198}$ McIntyre, 514 U.S. at 358 (Thomas, J., concurring in the judgment) (arguing that the Ohio statute should be overturned because the drafters of the First Amendment clearly believed that the right to publish anonymous political writings was included under the freedom of press).

${ }^{199} \mathrm{Id}$. at 342.

${ }^{200} I d$. at 345 n. 8 . 
Stevens forcefully concluded, "is a shield from the tyranny of the majority." ${ }^{201}$ Without the possibility of speaking anonymously, unpopular viewpoints may be silenced. Protecting anonymity thereby "exemplifies the purpose behind ... the First Amendment; ... to protect unpopular individuals from retaliation-and their ideas from suppression-at the hand of an intolerant society." 202 The McIntyre Court thus emphasized the importance of protecting anonymous speech for preserving contentneutrality in laws regulating speech.

Justice Scalia, in a dissent joined by Chief Justice Rehnquist, echoed Clark's dissent in Talley. Scalia argued that there is no "right-to-beunknown while engaging in electoral politics" ${ }^{203}$ and no general right to anonymity. ${ }^{204}$ According to Scalia, the majority's opinion creates a new right that is unclear, vague, and leads to "silliness." 205 The Ohio law, Scalia argued, served several important purposes: it promoted truthfulness in campaign literature, encouraged civility in campaigns, and ensured accountability. ${ }^{206}$ Although Scalia allowed that anonymity is required by the First Amendment when needed to "avoid threats, harassment, or reprisals," ${ }^{207}$ he argued that the general right to anonymity created by the majority in McIntyre is too broad with respect to this purpose.

Both Talley and McIntyre involved rather narrow statutes. Nevertheless, in each the majority defended anonymous speech by appealing to general arguments in favor of the right to anonymous speech and answered the dissenting Justices in part with theoretical arguments for protecting anonymous speech. Given the present composition of the Court, as well as the Court's commitment to stare decisis, it seems unlikely that McIntyre will be overturned or that the protections afforded anonymous speech will be weakened in the near future.

This prediction is supported by the recent case of Buckley v. American Constitutional Law Foundation, ${ }^{208}$ in which all nine Justices reaffirmed the importance of anonymous speech. At issue in Buckley were various restrictions on the process for adding voter initiatives to the Colorado ballot. Among the restrictions was a requirement that a person circulating a petition to get an initiative on the ballot must wear a badge stating her name, status as "volunteer" or "paid," and, if paid, the name and telephone number of her employer. ${ }^{209}$ The five-Justice majority compared Colorado's badge requirement to the ordinance at issue in McIntyre and found that the

${ }^{201} I d$. at 357.

${ }^{202} I d$.

${ }^{203}$ Id. at 371 (Scalia, J., dissenting).

${ }^{204} \mathrm{Id}$. at 379 (Scalia, J., dissenting).

${ }^{205}$ Id. at 381 (Scalia, J., dissenting).

${ }^{206} \mathrm{Id}$. at $382-83$ (Scalia, J., dissenting).

${ }^{207} \mathrm{Id}$. at 385 (Scalia, J., dissenting) (citations omitted).

208525 U.S. 182 (1999).

${ }^{209}$ Colo. Rev. Stat. § 1-40-112(2) (2002). 
restraint on speech ... [involved in the badge requirement] is more severe [than that involved in McIntyre because p]etition circulation is [a] less fleeting encounter [in that] the circulator must endeavor to persuade electors to sign the petition .... The injury to speech is heightened for the petition circulator because the badge requirement compels personal name identification at the precise moment when the circulator's interest in anonymity is greatest. ${ }^{210}$

Although the remaining four Justices disagreed with some aspects of the majority's reasoning concerning other elements of the Colorado statutes, Justice O'Connor (joined by Justice Breyer), Justice Thomas, and Chief Justice Rehnquist, in separate opinions, concurred with the majority's evaluation of the Colorado badge requirement. Although sharply divided on other issues, the Court was unanimous in finding that the Colorado badge requirement was unconstitutional because of its requirement that circulators display their names. ${ }^{211}$

While the protection for anonymous speech that emerges from Talley, McIntyre, and Buckley prevents the state from requiring an individual to identify herself when speaking in public, the protection of anonymous speech is not absolute. For example, the Court has suggested that it is consistent with free speech to require a corporation engaged in political speech to identify itself. In First National Bank of Boston v. Bellotti, the Court held, "Identification of the source of [corporate] advertising may be required as a means of disclosure, so that the people will be able to evaluate the arguments to which they are being subjected." ${ }^{212}$ Bellotti suggests that protections of anonymous speech do not extend to commercial speech. The Supreme Court has not, however, reached the question of the extent to which the protection of anonymous speech extends to non-political speech.

\section{Conclusion}

Current Supreme Court jurisprudence clearly protects anonymous political speech under the First Amendment. To determine whether or not a law is consistent with free speech, the Court will look, in part, to

${ }^{210}$ Buckley v. Am. Constitutional Law Found., 525 U.S. 182, 199 (1999).

${ }^{211} \mathrm{Id}$. at 217 (O'Connor, J., concurring in the judgment in part and dissenting in part) ("Requiring petition circulators to reveal their names while circulating a petition directly regulates the core political speech of petition circulation."); id. at 212 (Thomas, J., concurring in the judgment); id. at 232 (Rehnquist, C.J., dissenting) (citing McIntyre).

${ }^{212}$ First Nat'l Bank of Boston v. Bellotti, 435 U.S. 765, 792 n.32 (1978) (overturning a Massachusetts state law prohibiting corporations from making contributions to influence the vote on ballot questions that do not "materially affect" the corporation on the grounds that doing so would "abridge[] expression that the First Amendment was meant to protect."). 
whether and how such a law protects anonymous speech. In so doing, the Court will examine the theoretical arguments for protecting anonymous speech, especially those relating to the anonymous speech of unpopular minorities or of those with unpopular views whose speech might expose them to harm. In light of the social situation of lesbians and gay men and the saliency of the closet to that situation, lesbians and gay men qualify as the sort of unpopular minorities whose speech deserves the protections anonymity affords. The Parts that follow develop this line of thought in the context of cyberspace. Given the relative anonymity of speech in cyberspace and the role that such speech plays for gay men and lesbians, laws that restrict speech in cyberspace should be carefully examined for their effect on the speech of sexual minorities.

\section{Closetspeech And the First Amendment}

In this Part, I argue that the right to conceal one's sexual orientation in order to fully participate in public discourse is central to lesbians and gay men's ability to fully exercise their right to free speech. Put somewhat differently, gay men and lesbians cannot enjoy free speech unless, when they speak as gay men or lesbians, they are allowed to speak anonymously, either by using a pseudonym or by hiding their identities in some other fashion. As a shorthand, I use the term closetspeech for the speech of lesbians and gay men, when they speak as lesbians and gay men but do so anonymously. ${ }^{213}$ I argue in the following Part that, although the protections properly afforded closetspeech are not absolute, the social and legal reality of the closet, the First Amendment protections of anonymous speech, and the right to association demonstrate that closetspeech is at the core of the First Amendment. Attempts to restrict closetspeech should thus be subject to heightened scrutiny.

\section{A. Closetspeech as Anonymous Speech}

Starting in 1990 and continuing for a couple of years thereafter, a leaflet titled "Queers Read This" was distributed at lesbian and gay marches and in lesbian and gay venues. ${ }^{214}$ The flyer indicated that it was written and published "anonymously by queers." The leaflet said, in part,

How can I tell you[?] How can I convince you, brother, sister, that your life is in danger[?] That everyday you wake up alive, relatively happy, and a functioning human being, you are com-

${ }^{213}$ Kang, supra note 8, refers to a similar phenomenon in cyberspace pertaining to race as "cyber-passing."

${ }^{214}$ Anonymous, Queers Read This: I Hate Straights (1990), reprinted in We ARE Everywhere: A Historical Sourcebook of Gay and Lesbian Politics 773 (Mark Blasius \& Shane Phelan eds., 1997). 
mitting a rebellious act. You as an alive and functioning queer are a revolutionary. There is nothing on this planet that validates, protects or encourages your existence. It is a miracle that you are standing here reading these words. You should by all rights be dead ....

Straight people are your enemy. They are your enemy when they don't acknowledge your invisibility and continue to live in and contribute to a culture that kills you .... .

I hate Jesse Helms. I hate Jesse Helms so much I'd rejoice if he dropped down dead. If someone killed him I'd consider it his own fault. I hate Ronald Reagan too, because he mass-murdered my people for eight years .... I hate him for making a mockery of our grief. I hate the fucking Pope ... and I hate the whole fucking Catholic Church .... ${ }^{215}$

Despite its wide public distribution and its frequent use of "dirty words" and provocative speech, to my knowledge, no one was prosecuted for the publication or distribution of this anonymous flyer. In light of Buckley, McIntyre, Talley, and the discussion in Part V above, this is the right result. The people who published and distributed this controversial political leaflet had the right to do so anonymously. The discussion of anonymous speech in Part $\mathrm{V}$ establishes that when sexual minorities speak anonymously as lesbians, gay men, and bisexuals, their speech is at the core of the speech protected by the First Amendment.

Even the Justices who dissented in McIntyre would accept a more limited form of this argument. While the dissenters in McIntyre denied that there is a general right to speak anonymously, ${ }^{216}$ they allowed that a person is entitled to speak anonymously if necessary to avoid "threats, harassment, or reprisals." ${ }^{217}$ The McIntyre dissenters seem to have had in mind instances like the following. The Federal Election Campaign Act of 1971 required that political candidates and political action committees record and make available to the Federal Election Commission the name and address of every person who contributes more than ten dollars a year to them. ${ }^{218}$ In Buckley $v$. Valeo, the Court held that these requirements were constitutional because the government's interest in fair elections outweighs the possible infringement of the First Amendment rights of the parties involved. ${ }^{219}$ However, the Court held out the possibility that mi-

${ }^{215} I d$. at $773-74,776$. ing).

${ }^{216}$ McIntyre v. Ohio Election Comm'n, 514 U.S. 334, 371 (1995) (Scalia, J., dissent-

${ }^{217} \mathrm{Id}$. at 380 (citations omitted).

${ }^{218} 2$ U.S.C. $\S 432$ (Supp. III 1973) (current version at 2 U.S.C. $\$ 432$ (2000), changing, among other things, the $\$ 10$ threshold to $\$ 50$ ).

219424 U.S. 1 (1976). 
nority parties might be exempted from these disclosure requirements if they could "show ... a reasonable probability that the compelled disclosure of a party's contributors' names will subject them to threats, harassment or reprisals from either Government officials or private parties."220 In Brown v. Socialist Workers ' 74 Campaign Committee, the Court granted just such an exemption. The Court unanimously held that the risk of "threats, harassment or reprisals" was serious enough to exempt the Socialist Workers Party from disclosing the names of its contributors. ${ }^{221}$

Although both dissenters in McIntyre (Justices Scalia and Rehnquist) also dissented in Romer, they would perhaps acknowledge that in certain contexts, for reasons similar to those at play in Socialist Workers, lesbians and gay men might be subject to "threats, harassment or reprisals" for being open about their sexual orientation, for advocating lesbian and gay rights, or for engaging in provocative political speech (such as that contained in "Queers Read This"). Even the McIntyre dissenters should agree that lesbians and gay men are protected by the First Amendment when they speak anonymously about matters relating to lesbian and gay sexuality. Even if they do not, there remains a majority of the Court poised to recognize that closetspeech, as a controversial type of speech that is likely to inspire negative reactions, is at the heart of the First Amendment. For many lesbians and gay men, especially for lesbians and gay men living in the closest-in particular, lesbian and gay youth like Emmalyn Rood and Jeffrey, and lesbians and gay men who live in isolated contexts like rural areas or the military-cyberspace is an important and perhaps vital context in which to express themselves anonymously.

\section{B. No Flaunting, "Don't Ask, Don't Tell," and Similar Rules}

In Part III, I argued that it is a fairly well-entrenched legal fact that lesbians and gay men receive greater protection when their sexual orientations are kept private. For example, since the 1970s, judges, legislators, and officials of the executive branch have articulated rules that allow people to discuss homosexuality generally and/or to be homosexual without losing their government jobs. Under such rules, a lesbian or gay man is protected so long as he or she does not make his or her sexual orientation public. According to such rules, the government cannot restrict the speech of a gay man or lesbian so long as he or she keeps quiet about his or her sexual orientation. For example, under the military's policy concerning homosexuality, individuals who "don't tell" (and don't engage in "homosexual conduct") will supposedly not be discharged from the military on account of their sexual orientations. ${ }^{222}$ This policy did not

${ }^{220}$ Id. at 74.

221459 U.S. 87,101 (1982).

${ }^{222}$ See 10 U.S.C. $\$ 654$ (2000). 
develop in a vacuum. It is a well-accepted social maxim that a gay man or lesbian who keeps quiet about his or her sexual orientation will face fewer problems. ${ }^{223}$ Singer lost his job for "flaunting" his homosexuality, ${ }^{224}$ Rowland for not keeping her bisexuality to herself, ${ }^{225}$ and Shahar for publicizing her relationship with another woman. ${ }^{226}$ Perhaps all three would have avoided conflict had they remained silent; their speech would have been protected so long as they remained in the closet.

I am not defending the holdings of Singer, Rowland, and Shahar, all of which are problematic from both an ethical and an equal protection perspective. ${ }^{227}$ Rather, I am pointing to a thread that runs through a series of judicial decisions-the results of which are often hostile to sexual minorities and gay men-namely that lesbians and gay men receive greater First Amendment protection when they stay in the closet. This thread dovetails with a commonly held ethical intuition that the law should leave alone those lesbians and gay men who do not publicize their sexual orientations. This notion and the corresponding social intuition are both relatively weak, as I shall argue below. ${ }^{228}$ They are nevertheless sufficiently strong to sustain a free speech right of significance to lesbians and gay men, namely the protection of closetspeech.

Simply put, one source for the protection of closetspeech is that over the years, society and the state, through the actions of its various branches, have created and sustained the closet. The laws, executive orders, and court rulings that created the legal institution of the closet also created an obligation to protect people in the closet and their free speech rights. For example, the Ninth Circuit in Singer, by conditioning the extent of Singer's First Amendment protections to whether he kept his homosexuality discreet or flaunted it, ${ }^{229}$ intimated that Singer's speech would be protected by the First Amendment so long as Singer stayed in the closet. To some extent, when the state takes away the free speech rights of some homosexuals (those who flaunt their non-heterosexuality), it implicitly supports the speech rights of others (those who keep their sexual orientation quiet).

${ }^{223}$ Those who remain closeted are not immune from harm. Insofar as some people know one's sexual orientation, one is at risk of being "outed" (that is, of having one's homosexuality or bisexuality revealed). For a discussion of outing, see Gross, supra note 87; MoHR, supra note 87; John P. Elwood, Outing, Privacy and the First Amendment, 102 YALE L.J. 747 (1992); see also discussion of Sipple v. Chronicle Publ'g Co., 201 Cal. Rptr. 665 (Cal. Ct. App. 1984), infra text accompanying notes 235-238.

${ }^{224}$ Singer v. United States Civil Serv. Comm'n, 530 F.2d 247 (9th Cir. 1976), vacated,

429 U.S. 1034 (1977).

${ }^{225}$ Rowland v. Mad River Local Sch. Dist., 730 F.2d 444 (6th Cir. 1984).

${ }^{226}$ Shahar v. Bowers, 114 F.3d 1097 (11th Cir. 1997) (en banc).

${ }^{227}$ In fact, in Part VII, infra, I will argue that, in light of the considerations I discuss below, some aspects of the holdings of these cases undermine themselves.

${ }^{228}$ See infra Part VII, especially text accompanying note 262.

${ }^{229}$ See Singer, 530 F.2d at 249-50. 


\section{The Right to Association}

The Supreme Court has interpreted the First Amendment as providing strong protections for the right to free association, especially when such association has political and expressive purposes. The Court articulated this right in NAACP $v$. Alabama ex rel Patterson. ${ }^{230}$ As part of an attempt to prevent the NAACP from operating there, Alabama demanded the names and addresses of the association's Alabama members. The NAACP refused and was fined one hundred thousand dollars (a great deal of money in the 1950s). The Supreme Court held that Alabama's request for the membership list was unconstitutional because the "compelled disclosure of affiliation with groups engaged in advocacy" 231 restrains "the freedom to engage in association," "an inseparable aspect of the liberty [involved in] . . . the freedom of speech." ${ }^{232}$ Further, the court held that

compelled disclosure of [the NAACP's] membership is likely to affect adversely the ability of [the NAACP] and its members to pursue their collective effort to foster [their] beliefs . . . in that it may induce members to withdraw from the [NAACP] and dissuade others from joining it because of fear of exposure of their beliefs through their associations. ${ }^{233}$

Similar associational rights are involved in closetspeech. A person has a right to be a member of an association that advocates lesbian and gay rights, to subscribe to a gay or lesbian magazine, or to otherwise engage in associational activities related to sexual minorities without the risk of exposure. If a person's involvement in associational activities relating to her status as a sexual minority or her involvement in the lesbian and gay community puts her at risk of exposure or harm, then she will be more likely to restrict her involvement in the lesbian and gay community and, perhaps, retreat further into the closet. Closetspeech is thus closely connected to free association.

Similarly, the First Amendment prohibits the state from conditioning a person's right to speak on making her affiliations or beliefs known. For example, in Shelton $v$. Tucker, ${ }^{234}$ the Supreme Court held that the state could not require teachers to report all of the organizations with which they were affiliated because such a requirement would be an extreme and unjustified interference with the teacher's associational freedom. The Court's holding in Shelton appears to be in tension with the holding of Acanfora (which did not cite Shelton, despite its apparent relevance).

${ }^{232}$ Id. at 460; see also Bates v. City of Little Rock, 361 U.S. 516 (1960).

${ }^{233}$ Patterson, 357 U.S. at $462-63$.

234364 U.S. 479 (1960). 
Requiring Acanfora to reveal his membership in a gay organization seems to violate his First Amendment right to free association. For the state to compel a person to come out of the closet similarly violates the First Amendment. Just as free association is central to the First Amendment, so too is the protection of closetspeech.

\section{Sipple v. Chronicle Publishing Co.}

Protection of closetspeech, while central to the First Amendment, is not without limitations. While the state can neither force an individual to come out, nor condition her speech rights on whether she comes out, the First Amendment protection of closetspeech does not, generally, reach the actions of non-state actors. Consider the case involving the outing of Oliver Sipple.

In 1975, there was an assassination attempt on President Gerald Ford during which Oliver Sipple grabbed the arm of the president's would-be assailant, preventing Ford from being harmed. Subsequently, Sipple was hailed as a hero in the national press. Various articles, including one published by the San Francisco Chronicle, suggested that Sipple was gay, an implication that came as a surprise to some members of Sipple's family (and, some have speculated, prevented Ford from inviting Sipple to the White House). Sipple sued The Chronicle, the reporter who wrote the article in The Chronicle, and various others charging a tortious invasion of privacy. ${ }^{235}$ In upholding the trial court's grant of the defendants' motion for summary judgment, a California state appeals court identified three elements for a tort of invasion of privacy: (a) the facts disclosed must be private; (b) the facts must be disclosed in a public fashion; and (c) the facts disclosed must be offensive and objectionabie to a reasonable person with ordinary sensibilities. ${ }^{236}$ The court also noted that even a tortious invasion of privacy is exempt from liability if the facts published are true and newsworthy. ${ }^{237}$ The court implicitly granted that the facts were disclosed in a public fashion and that they were offensive and objectionable to a reasonable person, but it went on to hold that Sipple's homosexuality was already public in that he "spent a lot of time in ... well-known gay sections of San Francisco; that he frequented gay bars and other homosexual gatherings in [a variety of] cities; ... that his friendship with ... [a] prominent gay was well-known ...; and that his homosexual association and name had been reported in gay magazines ... several times before [the assassination attempt]. ${ }^{238}$ Further, the court held that Sipple's homosexuality was newsworthy. The court described

${ }^{235}$ See Sipple v. Chronicle Publ'g Co., 201 Cal. Rptr. 665 (Cal. Ct. App. 1984).

${ }^{236}$ Id. at $667-68$.

${ }^{237}$ Id. at 668 .

238 Id. at 669. 
Sipple as an "involuntary public figure" who, when he became a public figure, lost certain privacy protections that he would have had as a private citizen. For this reason, the First Amendment protections of Sipple's closetspeech did not trump the Chronicle's free press rights.

\section{E. Conclusion}

The First Amendment protects closetspeech. Given the ways in which the legal institution of the closet is created and maintained by the state, it is unconstitutional to require lesbians and gay men to come out in order to exercise their right to free speech. Accordingly, just as the First Amendment protects anonymous speech, it protects the anonymous speech of lesbians and gay men. The protection of closetspeech is especially robust because of the unique social situation of lesbians and gay men. In light of the role cyberspace plays for lesbians and gay mennamely, it provides a context in which to speak freely, without identifying themselves, and without having to be physically present to communicate with others-laws that restrict the closetspeech of lesbians and gay men in cyberspace warrant careful and critical judicial evaluation.

\section{Coming Out as Political Speech}

Although lesbians, gay men and other sexual minorities are in some ways safer and receive greater First Amendment protection when they are closeted, increasingly they are coming out of the closet and speaking out about issues of public concern. When lesbians and gay men speak outside the closet, what happens to their free speech rights? In this Part, I argue that when lesbians and gay men speak as open lesbians and gay menwhat I call "outspeech" (partly to emphasize the contrast with closetspeech)-their speech is political and thus deserving of strong protection under the First Amendment. I shall make this argument in two different ways. First, I argue that the act of coming out is political speech and thus it is at the heart of the First Amendment. Second, I build on the argument of Part VI. Given that closetspeech is paradigmatic of the speech that deserves the greatest protection of the First Amendment, it would be constitutionally impermissible viewpoint- or content-based discrimination if outspeech, the speech of open lesbians and gay men, were not similarly protected.

\section{A. "The Love That Dare Not Speak Its Name" Speaks}

Not more than a hundred years ago, homosexuality was dubbed the "love that dare not speak its name." ${ }^{239}$ Today, whether to celebrate or de-

${ }^{239}$ Lord Alfred Douglas, Two Loves (1896) quoted in The Oxford Dictionary 
ride it, people frequently discuss homosexuality in public forums, on television, in court rooms, in legislatures, and in almost every other context. The "love that dare not speak its name" is now unwilling to keep quiet. In fact, issues relating to homosexuality are so contentious that Justice Scalia said there is a "culture war" ${ }^{400}$ in this country about homosexuality. Given this trend as well as the social and legal situation of lesbians and gay men discussed in Part III, coming out-openly identifying as a lesbian, gay man, or bisexual-is a form of political speech. ${ }^{241}$ By coming out, one is effectively saying that being lesbian or gay is nothing to be ashamed of and, as such, coming out deserves the strongest protection of the First Amendment. More generally, outspeech-speaking as an open lesbian or gay man-is political speech on a topic of great public concern. Because outspeech is political speech, any state interference with such speech deserves the most exacting scrutiny of the courts. As the discussion that follows will demonstrate, courts have held that outspeech is political speech and thus deserving of the strongest protection under the First Amendment.

In 1980, Aaron Fricke, a high school student in Rhode Island, informed his principal of his desire to bring a same-sex date to the school's prom. The principal prohibited Fricke from doing so on the grounds that the presence of a same-sex couple would disrupt the prom and create a threat of physical harm to the couple and to others. Fricke filed suit in federal court. The district court held that Fricke's act of attending the prom with another man was a "political statement" and, hence, was protected as speech under the First Amendment. ${ }^{242}$ The court held that the principal's reasons for not allowing Fricke to bring a same-sex date to the prom failed to satisfy the "least restrictive means" prong of the test set forth in United States v. O'Brien. ${ }^{243}$ Further, the court held that the primary justification given by the principal for restricting Fricke's political speech-the threat of a violent or hostile reaction to his speech-is almost never an appropriate justification for restricting speech. ${ }^{244}$

of Quotations 255 (Angela Partington ed., 4th ed. 1992).

${ }^{240}$ Romer v. Evans, 517 U.S. 620, 652 (1996) (Scalia, J, dissenting).

${ }^{241}$ See, e.g., Bobbi Bernstein, Power, Prejudice, and the Right to Speak: Litigating "Outness" Under the Equal Protection Clause, 47 Stan. L. REv. 269 (1995); David Cole \& William Eskridge, Jr., From Hand-Holding to Sodomy: First Amendment Protection of Homosexual (Expressive) Conduct, 29 HARv. C.R.-C.L. L. Rev. 319 (1994); Janet Halley, The Politics of the Closet: Towards Equal Protection for Gay, Lesbian and Bisexual Identity, 36 UCLA L. REv. 915 (1989); Kenneth Karst, Boundaries and Reasons: Freedom of Expression and the Subordination of Groups, 1990 U. ILL. L. REv. 95, 117-20 (1990).

${ }^{242}$ Fricke v. Lynch, 491 F. Supp. 381, 385 (D.R.I. 1980).

243391 U.S. 367 (1968) (upholding a statute prohibiting the mutilation or destruction of a selective service registration card against a challenge on free speech grounds).

${ }^{244}$ See Fricke, 491 F. Supp. at 387 (citing Gregory v. Chicago, 394 U.S. 111 (1969) (holding that First Amendment protects a peaceful and orderly political demonstration even if onlookers become unruly as a result of the demonstration) and Terminiello v. Chicago, 337 U.S. 1 (1949) (holding that a city ordinance prohibiting breach of the peace infringed First Amendment rights when used to prosecute a person whose speech invited 
A similar view of the political nature of outspeech was expressed in the late 1970s when a group of four individuals and two gay rights organizations sued Pacific Telephone and Telegraph (PTT) under a California state law preventing employers from interfering with the political activities of their employees. ${ }^{245}$ The California Supreme Court held that this law applied to open homosexuals:

[T]he struggle of the homosexual community for equal rights, particularly in the field of employment, must be recognized as a political activity. Indeed the subject of the rights of homosexuals incites heated political debate today .... The aims of the struggle for homosexual rights, and the tactics employed, bear a close analogy to the continuing struggle for civil rights waged by blacks, women, and other minorities.

A principal barrier to homosexual equality is the common feeling that homosexuality is an affliction which the homosexual worker must conceal from his employer and his fellow workers. Consequently one important aspect of the struggle for equal rights is to induce homosexual individuals to "come out of the closet," acknowledge their sexual preferences, and to associate with others in working for equal rights. ${ }^{246}$

The court therefore held that PTT's policy of discriminating against what the court called "manifest" homosexuals ${ }^{247}$-namely "open" homosexuals, that is, people who "make an issue" of their homosexuality-violated California's labor code.

The courts in Fricke and PTT both accepted that coming out of the closet and being out as a lesbian or gay man is political speech. Together, these two cases stand for the proposition that outspeech is the sort of speech that is at the core of the First Amendment. ${ }^{248}$ Outspeech, like

public dispute and aroused anger)).

245 The statute states:

No employer shall make, adopt or enforce any rule, regulation or policy (a) [f]orbidding or preventing employees from engaging or participating in politics ... [or] (b) [c]ontrolling or directing, or tending to control or direct the political activities or affiliations of employees.

No employer shall coerce or influence or attempt to coerce or influence his employees through or by means of threat of discharge or loss of employment to adopt or follow or refrain from adopting or following any particular course or line of political action or political activity.

Cal. Lab. Code $§ 1101-02$ (West 1989).

${ }^{246}$ Gay Law Students Ass'n v. Pac. Tel. \& Tel. Co., 595 P.2d 592, 610 (Cal. 1979).

${ }^{247}$ Id. at 596.

${ }^{248}$ This view is further supported by a substantial body of legal and philosophical scholarship. See, e.g., Richard Mohr, Gays/Justice: A Study of Ethics, Society, AND 
other political speech, is paradigmatic of the type of speech that the First Amendment is designed to protect. Any attempt by the state to constrain or interfere with outspeech is highly suspect and should be carefully scrutinized by courts.

\section{B. Viewpoint Discrimination}

The Supreme Court has distinguished between content-based and content-neutral laws in evaluating the constitutionality of laws that regulate speech. A content-based law is one that regulates speech on the basis of its subject matter. Such laws are subject to strict scrutiny and are typically overturned. For example, in Police Department of Chicago v. Mos$l e y,{ }^{249}$ the Court struck down a Chicago law prohibiting all picketing outside of a school except peaceful picketing concerning a labor dispute. ${ }^{250}$ The Court held that the law impermissibly "restrict[ed] expression because of its message, its ideas, its subject matter, or its content." ${ }^{251}$ Similarly, in R.A.V. v. City of St. Paul, ${ }^{252}$ the Court struck down a St. Paul city ordinance prohibiting the placement of certain objects and symbols that arouse "anger, alarm, or resentment in others on the basis of race, color, creed, religion or gender." ${ }^{53}$ The Court held that the ordinance was "facially unconstitutional in that it prohibits otherwise permitted speech solely on the basis of the subjects the speech addresses." 254

The distinction between content-based and content-neutral laws can be coupled with the conclusion of Part VI-that laws restricting closetspeech cut against the central purpose of the First Amendment-to provide further support for the conclusion that outspeech is paradigmatic of the speech protected by the First Amendment. A state prohibition of outspeech but not closetspeech would be a content-based restriction on speech. Such a restriction would, for this reason, deserve strict scrutiny.

This seemingly straightforward argument is open to three objections. First, one might reply that while content-based restrictions on speech are often held to be unconstitutional, status-based restrictions on speech are sometimes permissible. For example, in Regan v. Taxation with Representation of Washington, the Court held that it was not a content-based restriction on speech to withhold tax benefits from any organization that

LAW (1988); supra note 241.

249408 U.S. 92 (1972).

${ }^{250}$ The ordinance at issue provides that a person commits disorderly conduct when she knowingly "pickets or demonstrates on a public way within 150 feet of any primary or secondary school building ... provided that this subsection does not prohibit the peaceful picketing of any school involved in a labor dispute . . .." Id. at 92-93 (quoting CHI., ILL., Municipal CoDE ch. 193-1(i) (1968)).

${ }^{251} I d$. at 95.

252505 U.S. 377 (1992).

${ }^{253}$ Id. at 380 (quoting St. Paul, MinN., Legis. Code $§ 292.02$ (1990)).

${ }^{254} \mathrm{Id}$. at 381. 
lobbies Congress unless it is a veterans' organization. ${ }^{255}$ That the restriction applied only to non-veterans' groups was held to be a status-based restriction rather than viewpoint-based restriction. ${ }^{256}$ Using similar logic, perhaps the differential treatment between the speech of open lesbians and gay men and the speech of closeted lesbians and gay men might be seen as status-based rather than content-based.

This line of argument is not promising. Many instances of contentbased restrictions on speech can be recast as isomorphic status-based restrictions on speech. For example, the law in Mosley ${ }^{257}$ could be recast to allow only union members (a status-based regulation) to picket rather than to allow picketing concerning labor disputes (a content-based regulation). Such a status-based law would presumably be unconstitutional since it has the same effect on speech as the law overturned in Mosley; a content-based restriction of speech does not become permissible simply because it refers to a speaker's status. Even allowing that the line between a status-based and a content-based regulation is unclear, a regulation of speech that distinguishes between outspeech and closetspeech is, at its roots, based on content, because it distinguishes speech on the basis of whether or not the speaker is open about his or her sexual orientation.

A second criticism of the argument that a state prohibition on outspeech but not closetspeech would be an impermissible content-based restriction appeals to the Supreme Court's decision in Hurley v. IrishAmerican Gay, Lesbian \& Bisexual Group of Boston, Inc., in which the court held that the state could not require the organizers of Boston's St. Patrick's Day parade to allow a group identified as lesbian and gay Irish people to march in the parade. ${ }^{258}$ While the parade organizers said they were willing to allow lesbians and gay men to march in the parade, they were not willing to let them march under a banner identifying them as an Irish American gay, lesbian, and bisexual group. ${ }^{259}$ The Court held that the First Amendment gives the parade organizers the right to control the content of their parade as they see fit: they may decide to include only those groups and individuals that contribute the particular expressive content to the parade that they desire. In Hurley, the Court seems to have accepted a content-based distinction, insofar as it found that it was legitimate for the parade organizers to distinguish between gay and lesbian marchers who were not identified as gay and lesbian, on the one hand, and gay and lesbian marchers who were so identified, on the other. If this

255461 U.S. 540 (1983).

${ }^{256}$ Id. at 548; see also Madsen v. Women's Health Ctr., 512 U.S. 753, 763 (1994) (holding that an injunction that restricted the speech of anti-abortion protestors was not a viewpoint-based restriction).

${ }^{257}$ Police Dep't of Chi. v. Mosley, 408 U.S. 92, 92-93 (1972).

${ }^{258}$ Hurley v. Irish-Am. Gay, Lesbian \& Bisexual Group of Boston, Inc., 515 U.S. 557, 566 (1995).

${ }^{259} \mathrm{Id}$. at 572 . 
distinction is legitimate in the context of Hurley, perhaps the distinction between outspeech and closetspeech is legitimate in other contexts as well.

Hurley can, however, be distinguished on several grounds. First, the Court did not address the question of whether the parade organizers were state actors (it was accepted that they were not). ${ }^{260}$ Hurley can therefore be distinguished from cases like Singer, Shahar, and Acanfora that clearly involve state action. It does not follow from the claim that private actors like Hurley and the South Boston Allied War Veterans Council, the organization he represented, may make a distinction between outspeech and closetspeech that a state actor can make such a distinction without thereby engaging in impermissible viewpoint discrimination.

Further, it is not clear to what extent Hurley survives Romer ${ }^{261}$ Consider whether the Court would have ruled differently if parade organizers had refused to let a group of African American marchers join the parade. Would the fact that racial classifications are subject to strict scrutiny have affected the outcome of such a case? If so, perhaps the Court's acknowledgement in Romer that sometimes classifications based on sexual orientations are impermissible would undermine the holding of Hurley.

A final criticism of the theory that the First Amendment protects outspeech is that this argument both relies on and undermines the logic of Singer and similar cases and is thereby an illegitimate form of argument. Recall, however, that my strategy here is to build on the conclusion of Part VI that the First Amendment protects closetspeech. In cases like Singer, courts have essentially held that closetspeech is protected but outspeech is not. My argument here is that to protect closetspeech but not outspeech is an impermissible form of content regulation. I am taking one part of the holding of cases like Singer (that closetspeech is protected) and showing that, in light of other well-established principles of First Amendment doctrine (e.g., the rule against content-based regulation of speech), another part of the holding of such cases (that outspeech can be regulated) is undermined. To borrow a metaphor from Ludwig Wittgenstein, I am "throw[ing] away the ladder after [I have] climbed up on it."262

${ }^{260} \mathrm{Id}$. at 566.

${ }^{261}$ See, e.g., Darren Lenard Hutchinson, Accommodating Outness: Hurley, Free Speech, and Gay and Lesbian Equality, 1 U. PA. J. ConST. L. 85 (1998) (arguing that restrictions on being openly gay, as in Hurley, are in tension with equality for sexual minorities).

${ }^{262}$ Ludwig Wittgenstein, Tractatus Logico-Philosophicus 189 (C. K. Ogden trans., Routledge \& Kegan Paul 1971) (1922). 


\section{Conclusion}

The preceding Part concluded that the First Amendment protects closetspeech and, thus, in light of the role cyberspace plays for lesbians and gay men, that the First Amendment strongly protects closetspeech in cyberspace. A parallel conclusion follows. The First Amendment protects outspeech by virtue of its political character. Laws that constrain outspeech are subject to strict scrutiny under the First Amendment. In light of the role that cyberspace plays for lesbians and gay men, attempts to restrict outspeech in cyberspace should also be strictly scrutinized.

\section{CONCLUSION}

In Part V, I argued that anonymous speech, especially anonymous speech on matters of public controversy, is paradigmatic of the speech at the heart of the First Amendment. The same arguments apply in cyberspace. If a present-day McIntyre decided to post on a Web site her material arguing against a referendum on a school tax or to send electronic mail to her neighbors encouraging them to vote on a referendum, her "cyber-pamphleteering" would deserve the same sort of First Amendment protection as the traditional pamphleteering at issue in McIntyre. The protections afforded anonymous speech extend to cyberspace. ${ }^{263}$ Further, the especially strong protection afforded the anonymous speech of unpopular minorities should be extended to the speech of lesbians and gay men in cyberspace.

As an illustration, consider the rest of Timothy McVeigh's story. After he discovered that AOL had illegally released his name to the Navy, McVeigh sent e-mail messages to every AOL user with the word "gay" in his or her member profile. In his e-mail message, McVeigh told the story of how AOL mistreated him. As news of what happened to McVeigh spread, many AOL users and others wrote to AOL, the White House, the Pentagon, and Congress. The dramatic response to McVeigh's "mass" e-mail encouraged him to sue the Navy and ensured that his case would receive widespread media attention. It also forced AOL to clarify its policy with respect to the privacy of its customers. ${ }^{264}$

McVeigh's cyber-activism is a vivid example of the role cyberspace can play in the organization of political and social change in the lesbian and gay community. McVeigh's cyber-activism would not have been as effective as it was (if it would have occurred at all) if lesbians and gay men did not have the opportunity to communicate anonymously that cyberspace affords them. Specifically, without the capability to anonymously identify as "gay" or "lesbian" in their AOL profiles, far fewer 
people would list their sexual orientations in such a manner. If they did not self-identify in this way, the type of cyber-activism in which McVeigh engaged would have been much less effective, or even impossible.

That the speech in cyberspace of lesbians, gay men, and other sexual minorities deserves strong protection does not entail that the First Amendment protects all anonymous speech in cyberspace, any more than it protects all anonymous speech outside of cyberspace. In fact, given the growth of computer viruses ${ }^{265}$ and cyberstalking, ${ }^{266}$ one might argue that the dangers of anonymous speech in cyberspace are greater than the dangers of anonymous speech in other contexts. Accountability is needed to prevent speakers in cyberspace from sending destructive viruses to other users, and anonymity does undermine such accountability. However, this reality fails to undermine the argument for anonymity in cyberspace. Computer crimes can be deterred and punished without prohibiting anonymity in cyberspace. Anonymity in cyberspace deserves at least as much protection as anonymity in the physical (that is, non-cyberspace) world.

Further, because of the special role that cyberspace plays for lesbians and gay men, attempts to regulate cyberspace by preventing anonymity will have a differential impact on lesbians and gay men. The arguments of Parts VI and VII entail that, in the current social situation, the speech of lesbians and gay men-whether outspeech or closetspeech-is at the core of the protections afforded by the First Amendment. Because of the closet and other features of their social situation, lesbians and gay men have special needs for the sort of anonymity that cyberspace provides. Like contributors to a small and unpopular political party, ${ }^{267}$ in various contexts lesbians and gay men face "threats, harassment, or reprisals" ${ }^{268}$ when they come out. As such, even judges who are skeptical of the right to anonymous speech, like the dissenters in McIntyre, should support anonymity for lesbians and gay men in hostile climates; protecting "persecuted groups .... [who] criticize oppressive practices and laws" 269 is at the very core of the First Amendment.

${ }^{265}$ See, e.g., Neal Kumar Katyal, Criminal Law in Cyberspace, 149 U. PA. L. Rev. 1003, 1023-27 (2001) (defining computer viruses and other types of unauthorized disruptions to computers); Michael Edmund O'Neill, Old Crimes in New Bottles: Sanctioning Cybercrime, 9 Geo. Mason L. Rev. 237, 252-53 (2000).

${ }^{266}$ See, e.g., U.S. DeP't of Justice, Cyberstalking: A New Challenge for LaW ENFORCEMENT AND INDUSTRY (Aug. 1999), available at http://www.usdoj.gov/criminal/ cybercrime/cyberstalking.htm; Katyal, supra note 265, at 1034-37 (defining cyberstalking).

${ }^{267}$ See Brown v. Socialist Workers '74 Campaign Comm., 459 U.S. 87, 88 (1982).

${ }^{268}$ McIntyre v. Ohio Elections Comm'n, 514 U.S. 334, 379 (1995) (Scalia, J., dissenting).

${ }^{269}$ Talley v. California, 362 U.S. 60, 64 (1960). 
Given the current social situation for lesbians and gay men, cyberspace provides a unique context for lesbians, gay men and other sexual minorities to build community, engage in activism, exchange ideas, make friends, and build families. Many lesbians and gay men, especially lesbian and gay youth like Jeffrey and Emmalyn Rood and lesbians and gay men who live in geographically isolated communities or in communities where they feel uncomfortable being open about their sexual orientation (for example, the military), make extensive use of cyberspace. The ability to use cyberspace anonymously is thus especially significant for lesbians and gay men. My argument that attempts to restrict closetspeech and outspeech should be carefully scrutinized is particularly applicable in the context of cyberspace.

The First Amendment, like the Constitution of which it is a part, is a living text that must be adapted to situations its drafters could not have imagined. Although the Framers could not have anticipated either the development of cyberspace or the particular social circumstances faced by sexual minorities, their text and the theories that informed it apply to both contexts. The speech of lesbians and gay men-and, in particular, their anonymous and political speech in cyberspace-deserves the strongest protection the First Amendment can provide. When legislatures craft statutes designed to regulate cyberspace, they need to consider the unique role that cyberspace plays in the lives of many lesbians and gay men. When courts evaluate the constitutionality of attempts to regulate cyberspace, they need, as most courts thus far have done, to protect the freedom of speech of sexual minorities. In particular, when courts face lesbian and gay litigants challenging attempts to regulate speech in cyberspace-as they so often have and will no doubt continue to do-they need to take special cognizance of the virtual lifeline that cyberspace provides lesbians and gay men and carefully scrutinize laws that trench on their First Amendment rights 